\title{
Macroeconomic policy regimes in emerging markets: the case of Latvia
}

\author{
Milka Kazandziska* \\ Berlin School of Economics and Law, Germany
}

This paper's goal is to analyse economic development in Latvia using the concept of a macroeconomic policy regime (MPR). An MPR consists of foreign economic policy, industrial policy, the financial system, wage policy, monetary policy and fiscal policy. This paper, furthermore, aims to explore the functionality of the development of these elements in Latvia based on one normative model of an MPR using a post-Keynesian approach. This paper suggests that to achieve a growth consistent with an external balance, foreign economic policy and industrial policy should be given high priority in restructuring the economy towards production and exports of high value-added products. The financial system needs to provide sufficient finance for the business sector and maintain the stability of the financial sector, while monetary policy will be in charge of providing low-cost finance to the financial system, secure its stability and maintain the stability of the exchange rate. Wage policy would be in charge of stabilising the inflation rate. Fiscal policy's main tasks would be to reduce the shocks to aggregate demand and reduce income inequality. It will be argued that the institutional changes in Latvia paved the way for a dysfunctional policy mix, of the sort that led to unstable economic development, high current account deficits, capital flow volatility, financial system instability, inflation rate volatility, and increasing income inequality.

Keywords: macroeconomic regime, open economy policies, emerging countries, industrial policy, Latvia

JEL codes: E02, E58, E61, E65, F41, F43

\section{INTRODUCTION}

This paper's goal is to analyse the economic development of Latvia as an emerging country using the concept of macroeconomic policy regimes (MPRs). The elements that constitute an MPR are: foreign economic policy, industrial policy, wage policy, monetary policy, fiscal policy and the financial system. The paper, moreover, aims at assessing the functionality

\footnotetext{
* This paper is part of my doctoral thesis on the topic of macroeconomic policy regimes in emerging countries. It has been presented at conferences and seminars in Riga, Oldenburg and Berlin. I am indebted to Eckhard Hein and Hansjörg Herr for their invaluable comments and generous support. I would also like to thank Nina Dodig and Daniel Detzer for proof-reading. Furthermore, I am grateful to Hans Böckler Foundation for the financial support.
}

Received 30 May 2013, accepted 24 March 2015 
of the development of these elements on the basis of one normative model from a postKeynesian perspective. ${ }^{1}$

Essentially, this paper postulates that a functional development of the elements of a regime creates the basis for sustainable economic growth supported by an external balance and a stable financial system, accompanied by low income inequality and a stable inflation rate.

This paper will focus on Central Eastern European countries (CEECs), in particular on the Latvian economy. Latvia has been chosen because it is small, open, and a net debtor country. It is also a country that, relatively early (by the mid 1990s), had deregulated its capital market and eliminated most trade barriers. From the mid 1990s until 2007 Latvia experienced a relatively strong boom (for which it was called the 'Baltic tiger') supported by high capital inflows especially in the real-estate and financial sectors. By 2008 the country had already slid into recession with dramatic losses in output, employment and capital outflows. It is one of the countries (together with Lithuania and Estonia) that experienced the strongest decline in output within the European Union (EU) (Eurostat 2014).

In terms of methodology, it is important to note that there are limitations to conducting a plausible econometric analysis of an MPR in Latvia because of the unavailability of continuous data with long time-period coverage. The concept of an MPR is, furthermore, of a highly complex and qualitative nature, and therefore the methodology consists first of reviewing the literature dealing with MPRs in emerging economies. Second, a Tinbergen type of approach is used, whereby each element of the MPR is assigned one or more main objectives, instruments to achieve the latter, possible strategies and institutions in charge. There are three criteria for assessing the functionality of the development of the specific elements of a MPR: achieving the objective they have been assigned; fulfilling the objective using the instruments suggested; and applying of the strategy proposed. For this purpose, specific indicators for the fulfilment of the objectives and the use of instruments and strategies will be suggested. On this basis, statistical data analysis and the use of descriptive statistics will be conducted.

In a nutshell, I will argue that economic policies in Latvia have been highly constrained by the liberalisation of the financial, labour and goods markets. These institutional changes have imposed very high limitations on the development of the MPR in Latvia, the outcome of which has been unstable economic development, high current account deficits, capital flow volatility, financial system instability, inflation rate volatility, and rising income inequality.

In Section 2 the contours of the model of an MPR will be set, and its elements will be addressed in detail. In Section 3 the focus will be put on the Latvian economy and the individual elements will be assessed on the basis of the model drafted Section 2. In Section 4 my conclusions will be presented.

1. The analysis of an MPR will be focused on the medium term because short-term developments tend to be influenced by changes in the business cycle (which are difficult to trace in emerging and developing countries, as the changes in the business cycles in these countries can be triggered by external factors). By contrast, long-run economic development is path-dependent; that is, it is affected by short- and medium-term economic development (see, among others, Herr/Kazandziska 2011b; Priewe/Herr 2005). 


\section{MODEL OF A FUNCTIONAL MACROECONOMIC POLICY REGIME}

The MPR as a concept was originally developed for industrial countries. ${ }^{2}$ There is a shortage of literature linking the MPR to emerging economies and this paper specifically aims to bridge this gap, focusing on the Central Eastern European countries (CEECs).

One important contribution to the literature dealing with the economic regimes of developing countries was made by Priewe/Herr (2005: 44), who used the term 'economic regime' to refer to a 'macroeconomic market constellation as a set of conditions and their interaction including economic institutions, which create growth or not'.

The present paper, however, takes on board the concept of the MPR which is distinct from the market constellation approach. With the MPR approach, an emphasis is put on both policies and institutions which are conducive to growth. Institutions set the framework for the application of policies. The government is not only a 'market participant', but first and foremost an actor that is able to change the current institutional framework in order to conduct macroeconomic policies in a functional way.

The elements of the MPR, as well as the tasks, instruments and strategies assigned to them, are developed in such a way as to match an open emerging economy. In this model, foreign economic policy and industrial policy play a very important role. Foreign economic policy is given the tasks of reducing the current-account deficits and achieving a balanced current account, and reducing the volatility of capital flows. ${ }^{3}$ Industrial policy is in charge of reviving the manufacturing sector by supporting investment in $\mathrm{R} \& \mathrm{D}$, production and exports of high value-added products and thereby eventually improving the terms of trade. The financial system supports both industrial and foreign economic policy by providing sufficient finance for companies (particularly operating in the manufacturing sector) and securing stability in the financial sector. Wage policy looks after for inflationrate stability by providing a stable anchor for prices (and for the real exchange rate, provided that the nominal exchange-rate anchor has been provided by monetary policy). ${ }^{4}$ Monetary policy secures the stability of the financial sector and provides low-cost finance to it, as well as maintaining the stability of the exchange rate. Fiscal policy's main tasks are to stabilise aggregate demand in the short and long run, and to reduce income inequality.

For these policies to achieve the most optimal results, coordination of and interaction between the elements of an MPR are necessary.

One solution for a functional MPR is illustrated in Table 1. However, other solutions are also possible. What follows is a separate analysis of the elements of an MPR and an assessment of their functionality by looking at the fulfilment of the assigned objective and the use of the proposed instruments and strategies.

\subsection{Foreign economic policy}

Based on the balance-of-payments-constrained growth model (BPCG) put forward by Thirlwall (1979), which showed that countries' growth is constrained by the balance of

2. The literature using specifically (macro)economic policy regimes to explain economic development is not particularly rich. Some important contributions can be found in Heine et al. (2006), Herr/Kazandziska (2011b) and Priewe/Herr (2005).

3. In the medium- to long-run, a country should aim to achieve a balanced current account. Currentaccount surpluses are not a universally applicable long-run growth strategy (Onaran/Galanis 2012; Priewe/Herr 2005).

4. A stable inflation rate is crucial for securing the stability of the exchange rate and the financial system, as well as for preventing capital flight and dollarisation (Priewe/Herr 2005). 


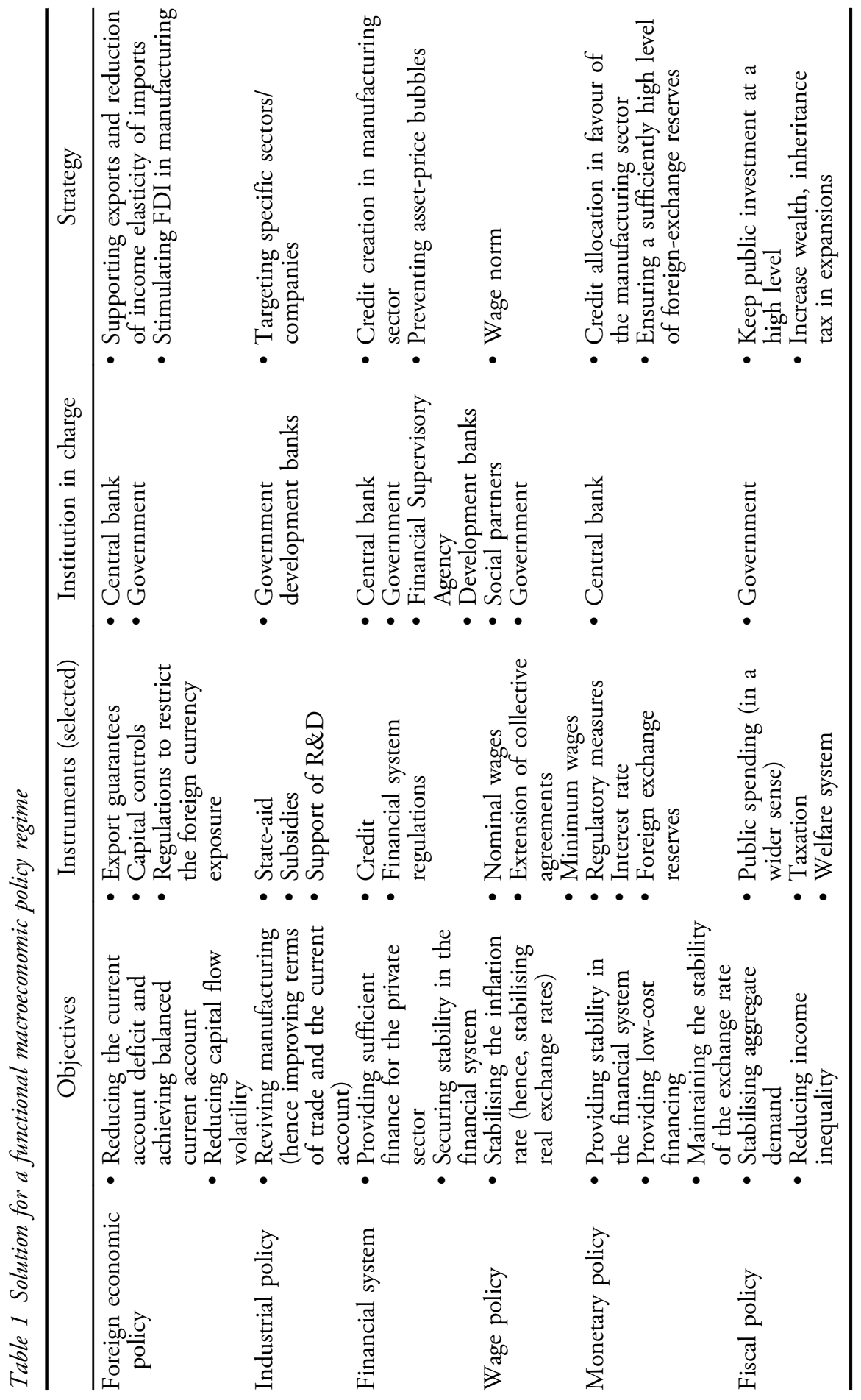


payments, we can set the first objective of foreign economic policy, which is the reduction of current-account deficits and the achieving of a balanced current account in the medium-tolong run. If a country has been successful in reaching this objective, it will be assessed using the indicator current account balance-GDP ratio. For the terms of the trade and the current account to be improved, it is of great importance that foreign economic policy and industrial policy are used in such a way as to restructure the economy in favour of the production and export of high value-added products (Thirlwall 1979). Subsidised loans for exporters, export credit guarantees, and the organisation of fairs and exhibitions are some of the instruments that can be used to increase the income elasticity of exports. However, it is highly challenging to find data about these instruments that is comparable across countries. Therefore, I am going to take a look at the medium-term development of government expenditure on export guarantees relative to the total value of exports. ${ }^{5}$ I can furthermore take a look at the change in scale and scope of government activities regarding the support of exports down the years. One strategy to apply in order to reach the first objective of foreign economic policy is to support particularly the manufacturing sector. The development of export guarantees allocated in the manufacturing sector (particularly in the high-end manufacturing sectors) in the medium run will be used to show us whether this strategy has been followed. ${ }^{6}$

The central bank and the government (which are the institutions in charge of foreign economic policy) are also given the task of reducing the volatility of capital inflows and outflows. Capital flows, particularly in emerging countries, are often crucial to the financing of imports, especially of primary and intermediate products needed for the process of production of domestic firms. But on the other hand they have very often been a source of disruption, causing the domestic currency to appreciate and current-account deficits to soar. The indicator that will be used to assess the functionality of foreign economic policy in achieving this goal is the mediumrun development of net financial flows, supplemented by the standard deviation of the latter as a measure of the capital flow volatility. Various instruments of capital flow management can be used to achieve this goal of foreign economic policy. ${ }^{7}$ Whether a country has used capital controls will be assessed by looking at the Chinn-Ito index. ${ }^{8}$ The higher the index, the higher the financial openness of the country; that is, the lower the level of capital controls used.

Under certain conditions, foreign direct investment (FDI) is the most desirable of all the different types of capital inflow because it does not automatically create an external liability (Herr/Kazandziska 2011b: 50; Priewe/Herr 2005). Thus, one strategy that could be followed is to employ capital controls in such a way as to restrict the inflow of speculative, short-term capital and support the inflow of long-term capital or FDI specifically in the high-technology sectors. The effectiveness of foreign economic policy in attracting FDI towards the productive sectors in the economy will be evaluated by looking at the share of FDI stocks in the manufacturing sector relative to the total FDI stocks.

In the next section, I will analyse the role of industrial policy as a part of a functional macroeconomic policy regime.

5. In this paper I am going to put my focus on the CEECs, whose government activities of export promotion are primarily concentrated on export guarantees.

6. High value-added sectors include the manufacturing of computers, pharmaceuticals and chemical products, scientific instruments, and electrical machinery (World Bank 2014).

7. They can range from a complete prohibition to possess a foreign currency (especially for the household sector), through a restricted access to foreign currencies, to diverse taxes on capital inflows and outflows (Priewe 2008; 2012).

8. The Chinn-Ito index is 'an index measuring a country's degree of capital account openness' (Chinn/Ito 2006 [2013]). A country can obtain a score within the range of -1.9 and 2.5. Notes on the definition and methodology of the calculation of the index can be found on the website: http:// web.pdx.edu/ -ito/Chinn-Ito_website.htm. 


\subsection{Industrial policy}

When discussing sustainable economic growth, particularly of the emerging countries, we ought to analyse the production structure of the economy. ${ }^{9}$ Similarly to other emerging countries, the Central Eastern European countries (CEECs) have undergone a process of de-industrialisation as the Soviet Union ceased to exist (Lux 2009). ${ }^{10}$ One negative effect of the de-industrialisation process, which can also be observed in the CEECs, is the increase in current-account deficits (Chang 1994: 57-58). Other possible effects are a reduction in employment (as medium and large enterprises are more likely to be found in the manufacturing than in the service sector) or a slower rate of productivity growth (Chang 1994: 58; Lux 2009). These arguments allow us to make the point that a revival of the manufacturing sector needs to be paid attention to, and for this to materialise, industrial policy needs to be brought to the fore.

Before I go into detail about optimal conduct - that is, the functionality of industrial policy - I need to say a few words about the concept of industrial policy used in this paper. First of all, the definition of the term 'industrial policy' used in the literature has been quite broad. ${ }^{11}$ I am going to follow Chang (1994; 2006; 2010), who defines industrial policy as a policy aimed at particular industries (and firms) that could increase the economic welfare of the whole country. I find that the definition of industrial policy developed by Chang fits the purpose of this paper most suitably.

Kaldor $(1970)$ and Thirlwall $(1979 ; 2011 ; 2013)$ argued in favour of the manufacturing sector as an engine for economic growth, whereby Thirlwall $(2011 ; 2013)$ emphasised particularly the positive contribution of the export of high-end manufactures to the reduction of balance-of-payments-constrained growth (BPCG). Hence, the development banks and the government departments in charge of industrial policy will be responsible, first and foremost, for bringing about a revival of the manufacturing sector as an important contributor to the total value-added in the economy, as well as a significant source of employment. The indicator used to assess the functionality of industrial policy in reviving the manufacturing sector is the development of the manufacturing output-total output ratio in the medium run. If the ratio shows a tendency of decline, we can talk about a failure of the industrial policy to achieve this objective. Different forms of state-aid can be used to support the firms operating in the manufacturing sector, which are engaged in R\&D activities and to stimulate the entry of new ones. The selected indicators to assess the use of industrial policy instruments are the sector-specific state-aid relative to the total state-aid, the state-aid to the manufacturing sector relative to the total state-aid, subsidies to the manufacturing sector-total subsidies ratio, government spending on research and development $(\mathrm{R} \& \mathrm{D})-\mathrm{GDP}$ ratio, and the government spending on $\mathrm{R} \& \mathrm{D}$ in the industry sector-GDP. ${ }^{12}$

One strategy to achieve the goal of revival of the manufacturing sector is targeting specific sectors/firms, which have the potential of reducing the income elasticity of imports and/or increasing the income elasticity of exports. These companies can be producers and

9. Due to space limitations, I will refrain from a detailed analysis of the production structure, and will instead concentrate on the manufacturing sector and the sectors that have often been the source of asset-price bubbles: the construction sector and the real-estate sector.

10. De-industrialisation can be measured as a declining share of the manufacturing output in total output and a declining share of employment in manufacturing in total employment.

11. For a systematic overview of definitions of industrial policy, check Warwick (2013).

12. Because of the fact that there are important aspects of industrial policy, which are not quantifiable (economies of scale, coordinating competing and complementary investments), the assessment of industrial policy functionality will be supported by a qualitative analysis as well (Chang 2010). 
exporters of high value-added products, as well as companies that have a vast number of linkages to other companies (in the high-technology sectors). Following this strategy would be beneficial also in terms of reducing the current-account deficits and eventually reaching a balanced current account. The existence of such 'targeted' or preferential industries will be used as an indicator for the application of this strategy.

It is especially important that the government sets up development banks and public commercial banks, which will provide favourable finance to the 'targeted' sectors and to the small and medium-sized enterprises (SMEs). This brings us to the analysis of the financial system, which follows in the next section.

\subsection{Financial system}

The importance of finance for economic development has been stressed by many post-Keynesian followers ${ }^{13}$ and by Keynes himself (Keynes 1937). Thus, the first objective of the financial system is to provide sufficient finance to companies and the first indicator I am going to analyse is the medium-term development of the corporate sector loans-GDP ratio.

The institutions in charge of the financial system are the government, the central bank, the financial supervisory agencies and the development banks. The creation of development banks is one of the important elements of a successful functioning of the financial system in emerging countries, as these banks are expected to fill in the gaps in the provision of long-term loans and loans to SMEs.

As the next step, I am going to look at the instruments of the financial system to provide finance for the companies. Low availability of credit - that is, the failure of banks to provide sufficient finance to the firms - could seriously impair the investment dynamic and the economic growth. I am going to use two indicators to assess the functionality of the financial system instruments to provide sufficient finance for the companies. The first is the so-called 'financial constraint' indicator of the World Bank, which can show us whether the demand for credit by the firms has been satisfied. ${ }^{14}$ The second indicator, 'availability of credit', supplements the former indicator. ${ }^{15}$

For an economy to develop in a sustainable way, it is necessary that the manufacturing sector as an engine for growth is given access to a sufficient amount of finance. Thus, one strategy that the financial system institutions can follow is to grant a sufficient amount of loans particularly to this sector. The indicators I am going to use are the medium-run development of the ratio of loans to the manufacturing sector relative to GDP and development of 'credit availability' in the manufacturing sector.

Maintaining the financial sector stability is the second objective of this element of MPR. The analysis of the indicators for assessing the functionality of the financial system in achieving this objective will start with an indicator of a banking crisis (the banking crisis dummy of the World Bank). ${ }^{16}$ The higher the frequency with which a country has

13. See, among others, Hein (2005), Herr (2008; 2014), Levine (2005) and Priewe/Herr (2005).

14. This indicator shows the percentage of firms that identified access to finance as being a major obstacle in their operations. For more information, see the World Bank's Enterprise Surveys data (available at: http://data.worldbank.org/data-catalog/enterprise-surveys).

15. 'Availability of credit' is calculated as the sum of the fully and partially accepted requests for bank loans relative to the total amount of requested loans (Eurostat 2014).

16. A banking crisis dummy is a binary measure for the banking crisis used by the World Bank. It will have a value of one if there has been a banking crisis and zero in the opposite case. More information about the methodology can be found on the website of the World Bank (http://databank. worldbank.org/data/). 
experienced banking crises, the higher the instability of the financial system. The second indicator is the development of the non-performing loans-total loans ratio in the mediumrun, whose increase can be interpreted as a sign of financial instability. The third and fourth indicators, the development of the foreign-currency loans-total loans ratio and the foreign-currency deposits-total deposits ratio in the medium-run, are measures of dollarisation (euroisation) in the country. The higher these ratios are, the higher the level of dollarisation and the higher the financial system's instability. The fifth indicator is the medium-term development of the foreign-currency loans-total household loans ratio, which will be taken as a measure of a currency mismatch.

There are vast and various instruments the financial system institutions can use to keep the financial system stable. ${ }^{17}$ However, as I'm focusing on emerging countries as open economies, in order to secure the optimal functioning of the domestic financial system and prevent a circumvention of the domestic regulations by the financial institutions, it is necessary that regulations are set that specifically include a foreign-currency provision. Hence, my analysis of the functionality of the financial system instruments will proceed by looking at the financial system regulations which entail a foreign-currency element. The medium-run development of regulations about the loan-to-value ratios specifically set for foreign-currency-denominated loans, loan-to-value ceilings for foreign-currency loans, or the reserve requirements on foreign-currency liabilities (or assets) are the indicators I am going to use (ECB 2014).

One strategy that can be followed to increase the financial system stability, particularly when there are signs of asset-price bubble development, is to discourage speculative investment of the companies by restricting the amount of loans granted to firms in the real-estate and construction sectors through different types of regulations. The mediumterm development of loans to the real-estate and construction sectors-total loans ratio will be used as an indicator to show us if the proposed strategy has been applied.

The next section will be devoted to wage policy.

\subsection{Wage development/policy}

Wages can potentially have negative effects on price development if they are flexible. Flexible nominal wages (when labour productivity is following an exogenous trend or is given and the mark-ups are constant) cause volatility in unit labour costs which, at least in a closed economy, are the most important determinant of prices (Hein/Truger 2005; Herr/Kazandziska 2007). The institutions in charge of wage policy are the social partners and the government.

From the aforementioned we can state that the main objective of wage policy is to stabilise the inflation rate and the indicator used is the medium-run development of the core inflation rate ${ }^{18}$ and the standard deviation of the latter to check its volatility. The main instrument of wage policy is the nominal wage and the first indicator I am going to analyse is the development of nominal wages in the medium-term.

Other instruments of wage policy (extension of collective agreements, minimum wages, automatic membership of workers in trade unions or automatic membership of firms in employers' associations) can also be used in order to achieve a high wage

17. See, for instance, Palley $(2000 ; 2004 ; 2006)$ for an overview of the regulatory instruments with counter-cyclical properties.

18. The core inflation rate excludes food and energy prices (OECD 2014). For more information, visit http://stats.oecd.org/. 
coordination, which contributes positively to the stability of the inflation rate. Extension of collective agreements can play a particularly important role in the wage development of emerging countries. Collective bargaining coverage is going to be used as an indicator for the functional use of the extension mechanism as an additional instrument of wage policy to achieve the goal of maintaining inflation-rate stability. The higher the coverage, the higher the functionality of this instrument.

Minimum wages can also complement wage policy in the process of wage coordination. The preconditions are that there is a link between the development of nominal wages and minimum wages and that a significant share of workers are covered by minimum wages (Herr/Kazandziska 2011a). However, we should bear in mind that even though the existence of extension mechanisms, minimum wages, etc., and their successful implementation could support wage policy, these instruments should not become a substitute for wage bargaining.

One suggestion for a functional wage policy strategy is the development of nominal wages, which takes into account productivity development and the inflation target for the economy, under the assumption of constant distribution claims (Hein/Stockhammer 2011: 130). The medium-term deviation of nominal wages from the wage norm ${ }^{19}$ signals a deviation of wage development from the suggested stability-oriented strategy.

The next section will encompass the analysis of monetary policy as a part of an MPR and the conditions for its functionality.

\subsection{Monetary policy}

There are three main tasks the monetary policy should be assigned: securing the financial system stability, providing sufficient low-cost finance for the banking system and maintaining the stability of the exchange rate. The central bank has a very important role to play in the process of regulation and supervision of the financial system (see, for instance, Arestis/Sawyer 2011; Palley 2000; 2004; 2006; Rochon/Rossi 2007; Sawyer 2011). The different instruments, which can be used to maintain the financial system's stability, have been analysed within the framework of the financial system as an element of an MPR. However, here I would like to mention particularly the instrument of credit allocation of the central banks. Especially crucial for emerging countries, which have experienced or are experiencing an asset-price bubble, is that the central bank trough (direct or indirect) credit allocation can channel credit to the manufacturing sector and away from the real-estate or financial sector. The existence of credit and interest-rate ceilings can be taken as an indicator of the involvement of the central bank in the credit allocation of the banking sector.

Central banks are also in charge of providing low-cost finance to the financial system. The difference between the real short-term rate of interest and GDP growth, as well as the real long-term interest rate and GDP growth, are going to be used as indicators for the ex-post provision of low-cost finance of the domestic central bank. The main instrument to reach this objective is the nominal interest rate and the indicator I am going to look at is the medium-term development of the nominal interest rate. The strategy that an individual central bank should follow in terms of the (nominal) interest-rate policy is a country-specific matter, which is going to depend on the country's capital account openness, the development of world interest rates, as well as the exchange-rate regime being followed.

Central banks should also worry about maintaining the stability of the exchange rate (and through this and under the condition that the wage policy fulfilled its task of keeping

19. The wage norm is calculated as the sum of the medium trend productivity increase plus the inflation target. 
the inflation rate stable, the monetary policy would also secure the stability of the real exchange rate). This can be achieved by adopting some form of a fixed exchange-rate regime. The medium-run development of the exchange rate between the domestic currency and the currency to which the domestic currency has been pegged ${ }^{20}$ will be used as an indicator for the stability of the exchange rate.

To achieve this objective, a country would need a sufficient amount of foreignexchange reserves. The development of foreign-exchange reserves in the medium term will show us whether the central bank used its main instrument (the foreign-exchange reserves) to maintain the stability of the exchange rate. Regarding the size of the foreign-exchange reserves, one strategy would be to maintain the former at a level sufficiently high as to cover the size of the external debt. A medium-run analysis of the foreign-exchange reserves-external debt ratio would be used to assess whether this strategy had been followed. The lower the ratio, the higher the danger of a default in repaying the external debt.

In the following section I am going to analyse the conditions for functionality regarding fiscal policy.

\subsection{Fiscal policy}

Fiscal policy has an important role to play in the economy. Post-Keynesian authors argue that fiscal policy, among others, should be assigned the role of real stabilisation in the economy, as well as achieving a more equal income distribution (Arestis/Sawyer 2004; Hein et al. 2012). Whether the fiscal policy manages to achieve the first objective (reduction of aggregate demand shocks in the short run) can be seen in the medium-run development of the output gap (or the real GDP growth). If the output gap is positive, then the economy is growing above capacity, while if it is negative, the capacity is underutilised. Stable economic development (without severe recessions) could be interpreted as a success of fiscal policy in reaching its first objective. Discretionary government spending (coupled by the work of the automatic stabilisers) should be used to combat demand shocks (Hein et al. 2012: 28). The cyclically-adjusted budget balance-potential GDP ratio will be used as an indicator for assessing the functionality of fiscal policy instruments. If this indicator increases (structural deficits fall) in a situation of crisis, then fiscal policy pro-cyclically restricts demand. If there is no change in the ratio, only automatic stabilisers are left to work (Hein/Truger 2007a).

One strategy that can be followed is to keep public investment at a sufficiently high level over the cycle and, particularly, to prevent its decline during recessions. Public investment (particularly in building infrastructure) stimulates private investment. It thus generates benefits for current and future generations (Hein/Truger 2014a). The development of the public investment-GDP ratio in the medium term will be used to check whether this strategy has been applied.

A government also needs to be involved in the redistribution of income towards lowerincome, lower-wealth households (Hein/Truger 2014a; 2014b). This is particularly important in emerging countries, as their welfare and taxation systems are at a lower level of development compared to the developed ones. The Gini index of market income will be used as an indicator for income inequality. Progressive taxation, property, wealth and inheritance taxes, extensive welfare systems including unemployment benefit schemes

20. In the countries that have adopted a flexible exchange-rate regime, the currency of the country's most important trade partner will be chosen. 
and social aid can be used to reduce income inequality (Hein/Truger 2014a; 2014b). The Gini index of disposable income will be used as an indicator for checking the functionality of the use of the aforementioned instruments in redistributing income towards low-income and low-wealth households. One strategy that can be applied is to increase property, wealth and inheritance taxes during periods of expansion. This strategy would contribute to a reduction of income inequality and at the same time also help prevent a development of asset-price bubbles, reduce saving rates and enhance the operation of automatic stabilisers. The development of property, wealth and inheritance taxes in the medium run is going to be used to assess whether the aforementioned strategy has been applied.

\section{MACROECONOMIC POLICY REGIME IN THE BALTIC REGION: A CASE STUDY OF LATVIA}

In what follows, the model of MPR will be used to examine the development of the Latvian economy. The focus will be put on the period 1995-2013. First, economic development and the contributions of elements of aggregate demand to growth will be analysed. Afterwards, a separate examination and assessment of all the elements of an MPR applied to Latvia will be provided.

\subsection{Economic development}

After the early transition phase in the first half of the 1990s (when Latvia experienced large losses of output, high inflation and increases in unemployment), in 1995 the economy started showing the first signs of stabilisation and recovery. During the years that followed, up until the outbreak of the financial crisis in 2008, the Latvian economy experienced uninterrupted growth of 6.7 per cent per year (Eurostat 2014). Owing to the deregulation of financial markets, as well as its entry into the European Union, Latvia attracted high capital flows which supported the creation of ever higher current-account deficits. The inflows of capital were predominantly channelled in the form of credit to the service sector (specifically the real-estate, financial and construction sectors) and to households, which boosted consumption as the main driver of growth in the economy (Figure 1). This can also be seen in the development of the financial balances of the different sectors (Figure 2). During the period of expansion, the main imbalances occurred in the private sector and in the current account as a result of the capital inflows. The spending of the government was slightly higher than tax revenues during the late 1990s and the early 2000s. Yet we can observe that the deficit of this sector declined and reached around zero in the 2 years preceding the financial crisis.

However, the relatively high economic growth in the boom period was not supported by an employment creation. In fact, employment increased only at a rate of 0.35 per cent on average between 1995 and 2007 (Eurostat 2014). ${ }^{21}$ Therefore, we can speak of a jobless growth in Latvia.

In 2008 the Latvian economy slid into a recession that lasted until 2011. Latvia was among the European countries that were hit the hardest by the financial and economic crisis. Both private consumption and investment fell sharply in 2008. As a result of the bursting of the bubble in 2008, the balances of the private sector turned positive and the current-account deficits were reduced. Yet the positive contributions of net exports to GDP growth were registered only in 2008 and 2009, owing to the collapse of imports

21. It is because of the strong and prolonged increase in GDP rather than in employment that we can observe big increases in productivity, starting from 1996. 


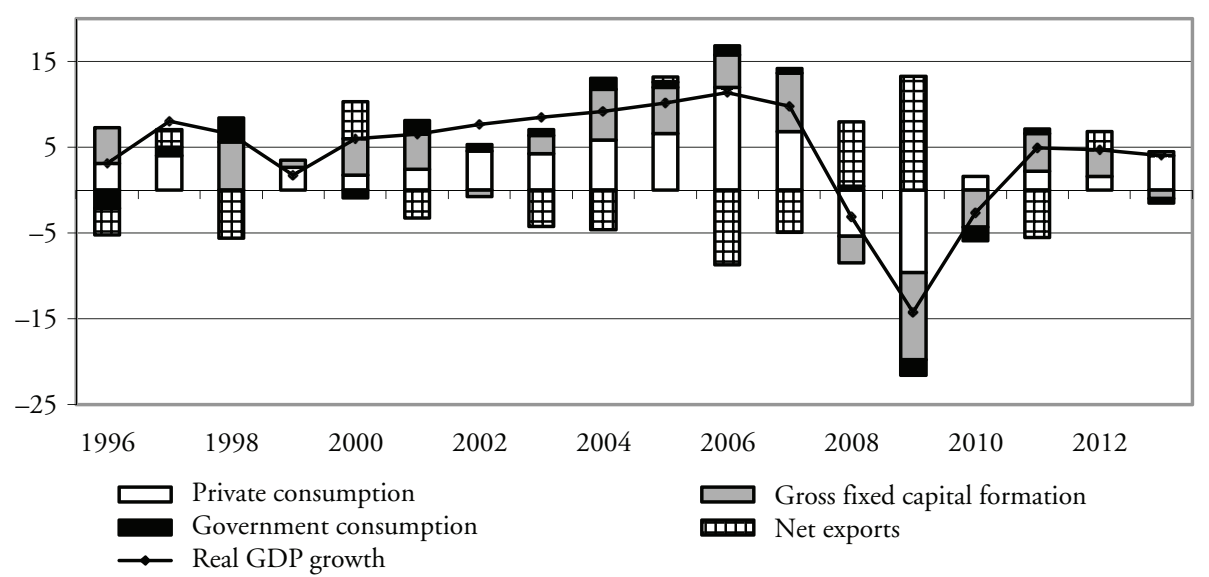

Notes: a. The contributions of the components of aggregate demand do not add up to the real GDP growth rate because the change of inventories and acquisitions less disposals of valuables is not included in this figure.

Source: Eurostat (2014), author's calculations.

Figure 1 Contributions of components of aggregate demand to real GDP growth in Latvia, (percentage points), 1996-2013

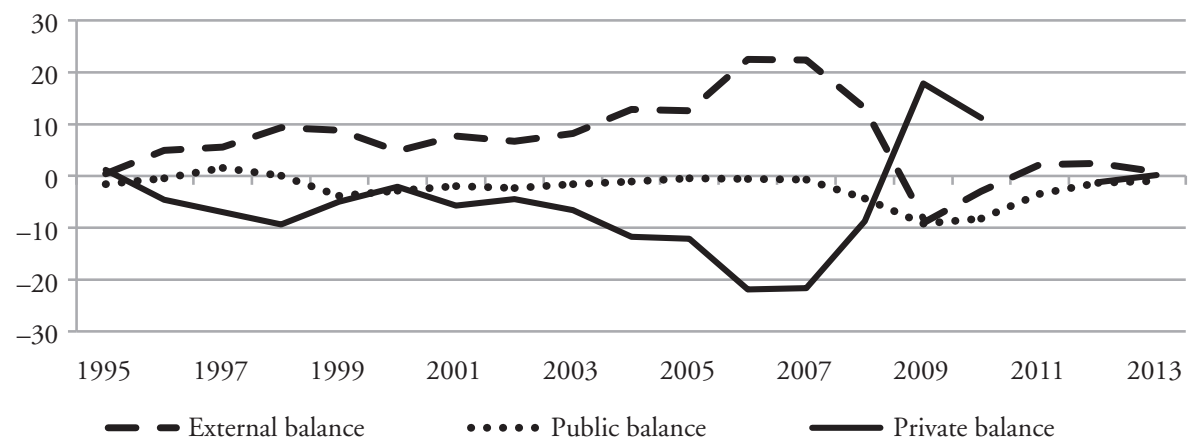

Source: Eurostat (2014).

Figure 2 Financial balances of the private sector, the public sector and the rest of the world (relative to GDP, per cent), Latvia, 1995-2013

in the face of the severe cuts in wages, increases in unemployment and the loss of purchasing power. Higher government spending was needed to absorb the excess of saving over investment. However, in 2009 the EU Council decided that Latvia had excessive public deficits and had to undergo an excessive deficit procedure, with cuts in government spending which, coupled with very large declines in private consumption and investment, was a very important cause for the reduction in GDP growth of around 18 per cent in 2009. The economy started recovering in 2011, as consumption picked up. However, the 
positive contribution of consumption to economic growth has not been nearly as high compared to the 'boom' phase, while the contribution of investment to economic growth after 2011 was declining.

In what follows, I will concentrate on the analysis of the elements of an MPR. The first element that will be examined is the foreign economic policy.

\subsection{Foreign economic policy}

Foreign economic policy has been influenced by two major institutional changes: capital market deregulation in the mid 1990s and Latvia's accession into the EU in 2004. These changes induced a surge in capital imports, which was one important reason for the dramatic increase in the current-account deficits. Thus, we come to the initial point of the analysis in this section: functionality of foreign economic policy in achieving its first goal, which is the reduction of current-account deficits and the achieving of a balanced current account.

Figure 3 shows that the current-account deficits were becoming ever larger until the outbreak of the financial crisis. Even though the biggest imbalance was created in the trade of goods and services, as the capital inflows progressed, there appeared a deficit in the income account as well. ${ }^{22}$ During the financial crisis, the current-account balance turned positive, as a result of a decline in import demand and the financial losses of foreign investors.

However, as the economy started recovering, current-account deficits began rising. Bajo-Rubio/Díaz-Roldan (2009) and Kvedaras (2005) estimated that the balance-ofpayments-constrained growth rate for the Latvian economy was higher than the actual GDP growth rates, which means that the country has been growing faster than the external constraints would allow, because of the current-account deficits.

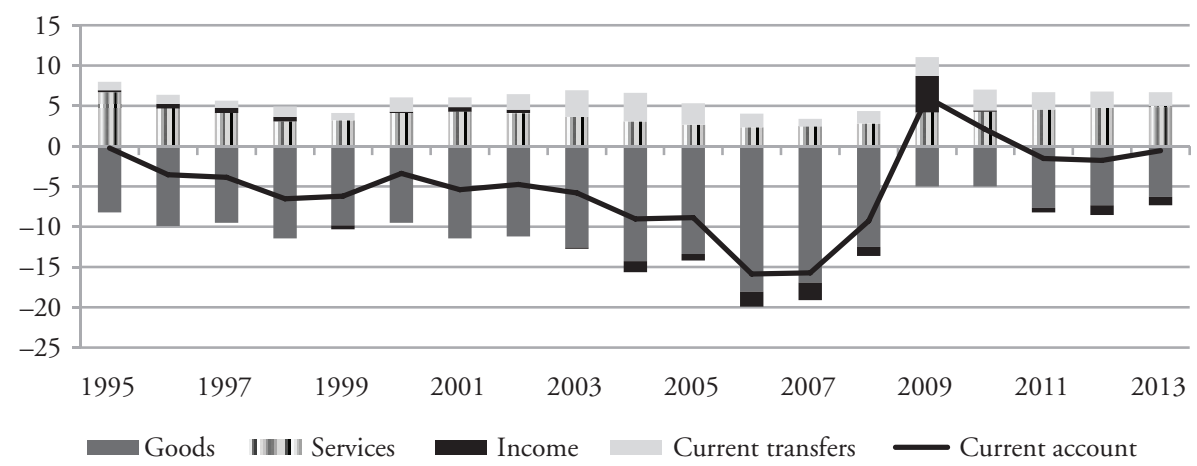

Source: Bank of Latvia (2014), author's calculation.

Figure 3 Structure of the current-account balance (relative to GDP, per cent), 1995-2013

22. Starting from 2003, cumulative interest payments, as well as profit repatriation, led the balance of the income account to turn negative (Eurostat 2014). 
This brings us to the point that an economic restructuring leading to increased production and exports of high value-added products is necessary. On average, during the period 1995-2012, the share of high-technology products in total manufactured exports has been below the EU average (5.8 per cent in Latvia and 8.2 per cent in the EU-15) (World Bank 2014). I am going to examine to what extent the government used the proposed financial instruments (export subsidies, export guarantees, tax deductions, favourable loans, direct credit, etc.) and non-financial instruments (training, organisation of fairs, advertising, market surveys, etc.) to reduce the current-account deficit and achieve a balanced current account. It is a great challenge to find data about the use of these instruments, especially for Latvia, as its government introduced an active export promotion strategy only recently. Most of the offered government supports for exporters is in the form of undertaking market research, organisation of trade missions, seminars, national stands and company matchmaking (Andersone/Bogdanova 2013). Out of the limited financial instruments the government used to support the exporters, I am going to focus on export guarantees. Until 2009, there has been a rise in the amount of exports covered by guarantees. ${ }^{23}$ However, in the period thereafter, the value of export guarantees fell relative to the value of exports back to the level of 0.1 per cent in 2012 (Latvian Guarantee Agency). According to Andersone/Bogdanova (2013), the number of export guarantees in Latvia has been lower than in the EU (2013). ${ }^{24}$ The fact that the biggest share of guarantees in all the years for which there are available data (2009-2012) have been granted in the wood and wood-processing industry (which is not a high value-added industrial sector) justifies the argument that there has been a lack of success in improving the income elasticity of exports; that is, the proposed strategy has not been followed.

The second objective of foreign economic policy is reducing the volatility of capital flows. Figure 4 shows that the capital flows in Latvia have not been stable. This argument is supported by the fact that the standard deviation of the net capital flows for the period 1995-2013 amounts to 8.3, which is significantly higher than, for instance, the standard deviation of capital flows in the EU average, whose value is 1.2 (author's calculation based on Eurostat 2014).

The capital inflows in Latvia were predominantly in the form of interbank and intercompany loans as a part of other investment flows (Figure 4). This type of capital inflow created an external liability and caused an increase in the level of external debt, which increased the vulnerability of the financial system (see also Section 3.4). The second important source of international finance has been FDI. The biggest share of FDI inflows went to the financial and real-estate sectors.

Next I am going to look at the indicator for the use of instruments (capital controls) to prevent a fluctuation in capital flows. We can see that the Chinn-Ito index has been relatively high during the period 1995-2007 (Table 2). The process of capital account liberalisation in Latvia took place relatively quickly. ${ }^{25}$ This speaks of a very high level of capital account liberalisation in Latvia, which equals the level of capital openness of the EU

23. The share of exports covered by export guarantees increased from 0.1 per cent in 2006 to 0.4 per cent in 2009 (Latvian Guarantee Agency).

24. One of the main and most important reasons for this limited success is the condition to grant guarantees for exports only to non-EU and non-OECD member countries, which imposes a serious constraint on the domestic companies as the EU has a share of around 70 per cent in the total Latvian exports (Central Statistical Office of Latvia 2014).

25. In 1997, the Chinn-Ito index in Latvia had already reached 2.2. In 2003, it reached the highest value possible (2.4) and remains at this level today (Chinn/Ito 2006 [2013]). 
332 European Journal of Economics and Economic Policies: Intervention, Vol. 12 No. 3

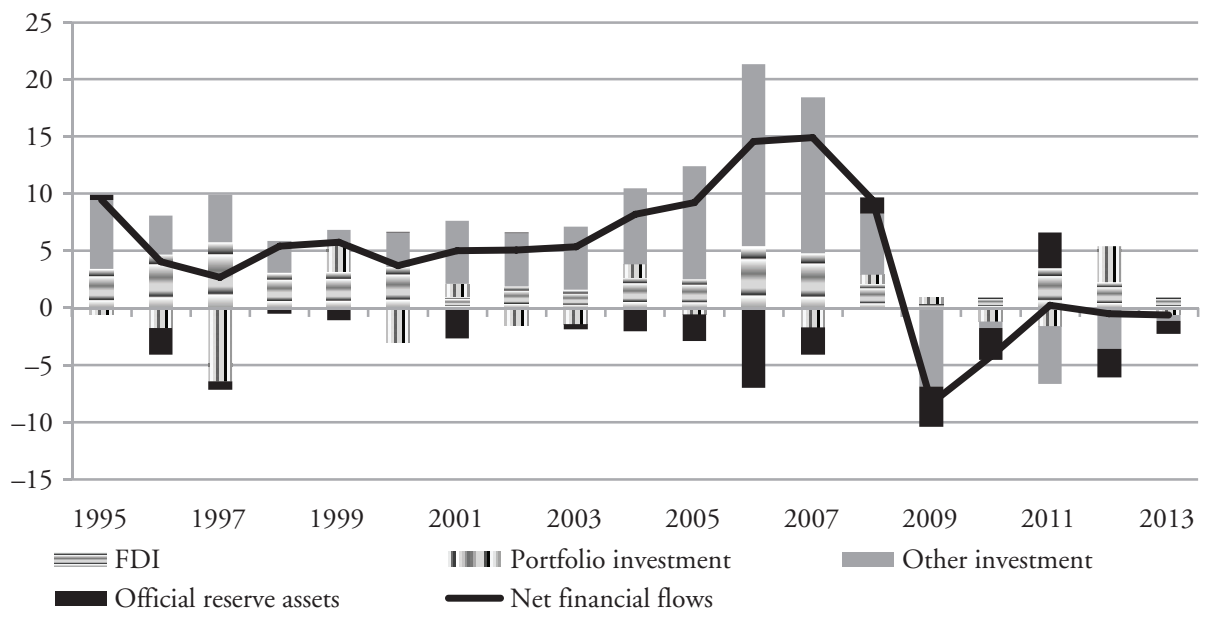

Source: Bank of Latvia (2014), author's calculation.

Figure 4 Structure of capital flows, net (relative to GDP, per cent), Latvia, 1995-2013

Table 2 Foreign economic policy indicators, average values, 1995-2012

1995-2007 2008-2012

Export guarantees (relative to total exports, per cent) in Latvia

Chinn-Ito index for capital account openness (Latvia)

Chinn-Ito index for capital account openness (EU-15)

$0.1^{\mathrm{a}} \quad 0.3$

$2.2 \quad 2.4$

$2.3 \quad 2.4$

Notes: a. The calculation starts in 2005 as data are not available for prior years.

Source: Chinn/Ito (2006 [2013]) for the Chinn-Ito index and the Latvian Guarantee Agency for export guarantees.

Table 3 Inward direct investment stocks by economic activity (share of total inward FDI activities, per cent) in Latvia, average values, 1995-2013

\begin{tabular}{lcc}
\hline & $1995-2007$ & $2008-2013$ \\
\hline FDI to the manufacturing sector & 13.1 & 11.7 \\
FDI to the construction sector & 4.0 & 6.1 \\
FDI to the financial sector & 23.8 & 29.4 \\
FDI to the real-estate sector & 8.6 & 11.0 \\
\hline
\end{tabular}

Source: Bank of Latvia (2014), author's calculation.

countries (Table 2). We can conclude that the government did not seem to functionally apply the proposed instruments of capital management to prevent high capital volatility.

Furthermore, the strategy of channelling FDI away from the speculative activities and towards the manufacturing sector seems not to have been applied (Table 3). As we can see from Table 3, the stocks of FDI in the financial, real-estate and construction sectors even 
increased amidst the financial crisis, while in the manufacturing sector we can observe a decline. Because of the fact that the FDI flew mainly towards services, which are to a large extent non-tradable, we could argue that the influx of FDI could to a certain extent have supported a deterioration of the current account (Mencinger 2007).

Because the goals of foreign economic policy - reducing current-account deficits, achieving a balanced current account and reducing capital volatility - were not achieved and the proposed instruments and strategies were either not applied or their size (as in the case of export promotion) was inappropriate for the goals they were meant to achieve, we can speak of dysfunctional foreign economic policy. The open capital account led to an overvalued currency, a currency mismatch in the balance sheets and ever-increasing current-account deficits in an economy whose production and export structure is concentrated in the wood and wood-processing industry. The success of industrial policy in changing the production and export composition in Latvia will be stressed in the next section.

\subsection{Industrial policy}

Perhaps one of the most important institutional changes, which has had a major impact on the industrial policy in Latvia, is the accession into the EU. The entry into the EU restricted the use of sector-specific industrial policy in this country. Hence, we can observe a drastic decline of sectoral state-aid starting from 2004.

The major role that industrial policy plays in this model is the reviving of the manufacturing sector. The indicator I am going to look at is the medium-term development of the output in the manufacturing sector-total output ratio. Unlike the construction sector, which showed an increase during the years of economic expansion, the output in the manufacturing sector has shown a tendency towards decline (Figure 5). Furthermore, the sectoral composition of output reveals that even within the manufacturing sector, high-technology, high value-added sectors have had a relatively limited importance. ${ }^{26}$

Out of the three different sectors (agriculture, industry and services) the growth of the Latvian economy after the mid 1990s was predominantly driven by the service sector. The increase in value-added in the service sector occurred particularly in the real-estate, wholesale, retail trade, transport and accommodation sector. ${ }^{27}$ From the above, we can conclude that the first objective of industrial policy in reviving the manufacturing sector has not been met.

The second criterion of assessment of industrial policy functionality is the use of the appropriate instruments to achieve the primary goal of industrial policy. The first indicator I am going to examine is the non-crisis, sectoral state-aid-total state-aid ratio. Figure 6 clearly shows that although in 2000 sectoral state-aid in Latvia was higher than the EU average, since 2001 the former has declined below this average and in 2004 reached a level of 0 per cent. The same is true about the state-aid to the manufacturing sector, which amounted to 0 per cent in 2004 and during the period 2007-2011.

Very similarly to what was said about state-aid, the third indicator - subsidies to the manufacturing sector-total subsidies ratio - has also equalled zero and has been much

26. For the period 2000-2010, the share of the high-technology, manufacturing sectors in the total output was 1.2 in Latvia and 5.4 per cent in the EU-13 countries (Luxemburg and Ireland are excluded from the calculation of the EU average owing to lack of data; hence, I take here the average of the EU-13 countries) (authors' calculation based on Eurostat 2014).

27. However, there has been only a moderate increase in employment in these sectors, although they have been the biggest recipients of finance from the banking sector. 


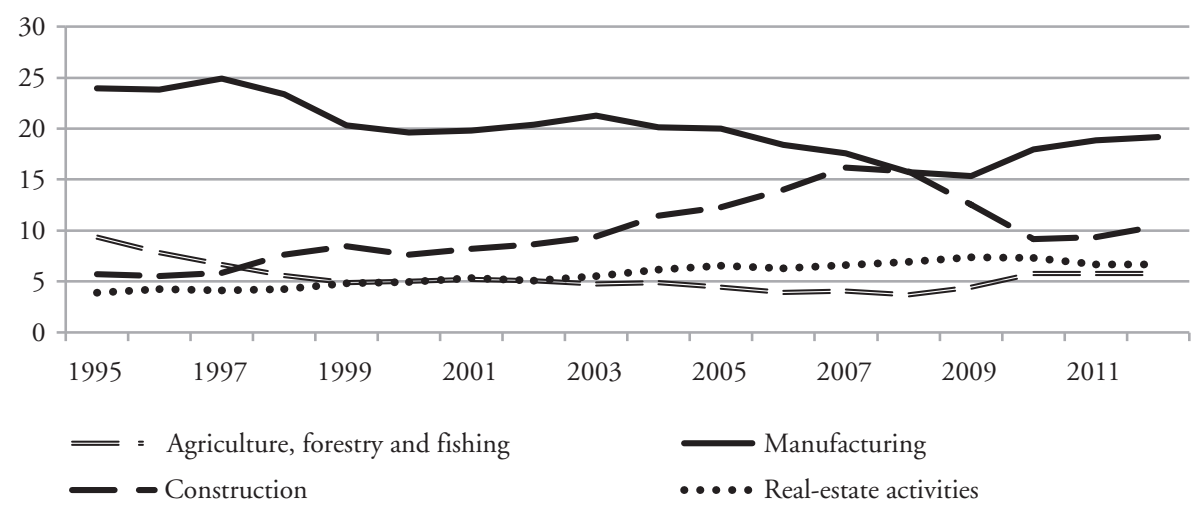

Source: Eurostat (2014), author's calculation.

Figure 5 Sectoral composition of output in Latvia, 1995-2012 (share of total output, per cent)

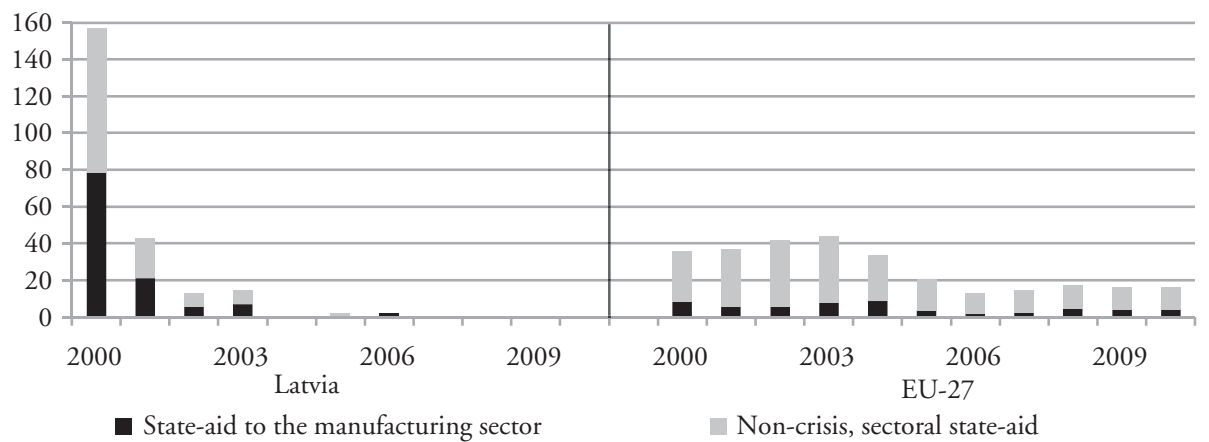

Source: European Commission (2014a), author's calculation.

Figure 6 Sectoral state-aid in Latvia and EU-27 (share of total state aid, per cent), 2000-2010

lower than in the EU average (Table 4). ${ }^{28}$ The next indicators - the government spending on R\&D-GDP ratio and the government spending on R\&D in manufacturing sectorGDP ratio - have both been lower than the EU average for the whole period under observation (1995-2012).

The narrative part of the analysis of industrial policy starts in 2009, when the first attempts to introduce industrial policy were made, but with little success, as there seemed to be a lack of consensus between the Bank of Latvia and the Ministry of Economics on the choice of targeted sectors (Dombrovsky 2010). In 2013, in the Economic Development Report, the government acknowledged the need for the use of industrial policy to eliminate the market and state failures and to 'minimize the need for state intervention' (MoE 2013). In this report, industrial policy is supposed to promote a structural change in the economy in favour of the production and export of higher value-added

28. The data source is Eurostat (2014) and the period for which data are available is 2007-2012. 
Table 4 Industrial policy indicators in Latvia and the EU, average values, 1995-2012

\begin{tabular}{ccc}
\hline & $1995-2007$ & $2008-2012$ \\
\hline Subsidies to the manufacturing sector relative to total subsidies (per cent) \\
Latvia & 0.0 & 0.0 \\
EU-15 & 1.7 & 1.4 \\
Government spending on R\&D relative to GDP (per cent) & \\
Latvia & 0.2 & 0.2 \\
EU-15 & 0.7 & 0.7 \\
Government spending on R\&D in manufacturing relative to total government \\
spending (per cent) \\
Latvia \\
EU-15 & 0.0 & 0.0 \\
& 0.2 & 0.1 \\
\hline
\end{tabular}

Note: a. Owing to lack of data, the calculation of the CEECs average for the period 1995-2003 starts with the year 1999. For the same reason, Hungary is excluded from the CEECs average until 2004.

Source: Eurostat (2014).

products. ${ }^{29}$ Nonetheless, a systematic industrial policy strategy focusing on the support of particular industries (or firms) is lacking. With that being said, we can conclude that the application of the strategy of targeting specific sectors/firms has also been unsuccessful. Furthermore, as noted in the government's report, there is a shortage of resources available for the conduct of industrial policy, and their collection would highly depend on the size of the structural funds approved by the EU for the aforementioned purposes.

From the above, we can conclude that industrial policy has not fulfilled its main objective and has not sufficiently used the instruments and the strategy for a functional industrial policy proposed in this paper. Only in 2013 did the government make its first attempts at conceptualising industrial policy. It is too early to discuss the possible outcomes of the recent interest by the government to include industrial policy in the economic development toolkit. Yet it seems like industrial policy in the government's view should be applied to the whole economy, not just targeting certain sectors. Hence the influence of the EU policy restrictions on the industrial policy of Latvia is to be seen.

\subsection{Financial system}

I will start this section by providing some background information about the institutional framework in which the financial system was operating and its changes since the beginning of the 1990s. By the early 1990s, the Latvian government had already decided to remove most restrictions to entry for banks and other financial institutions, which marked the official start of the financial system's deregulation. By the mid 1990s, most credit ceilings, credit controls and restrictions on international capital flows had been eliminated (IMF 2008: 769-776). As the stock market grew, firms could increasingly obtain finance in the capital markets, which also stimulated a rise in stock prices. ${ }^{30}$

29. It is planned, among other things, that the investment in $R \& D$ reaches a level of 1.5 per cent of GDP and that the share of manufacturing reaches 20 per cent of GDP by 2020 (MoE 2013). 30. The Riga stock exchange index increased by more than 120 percentage points between the first quarters of 2004 and 2007 (Eurostat 2014). 


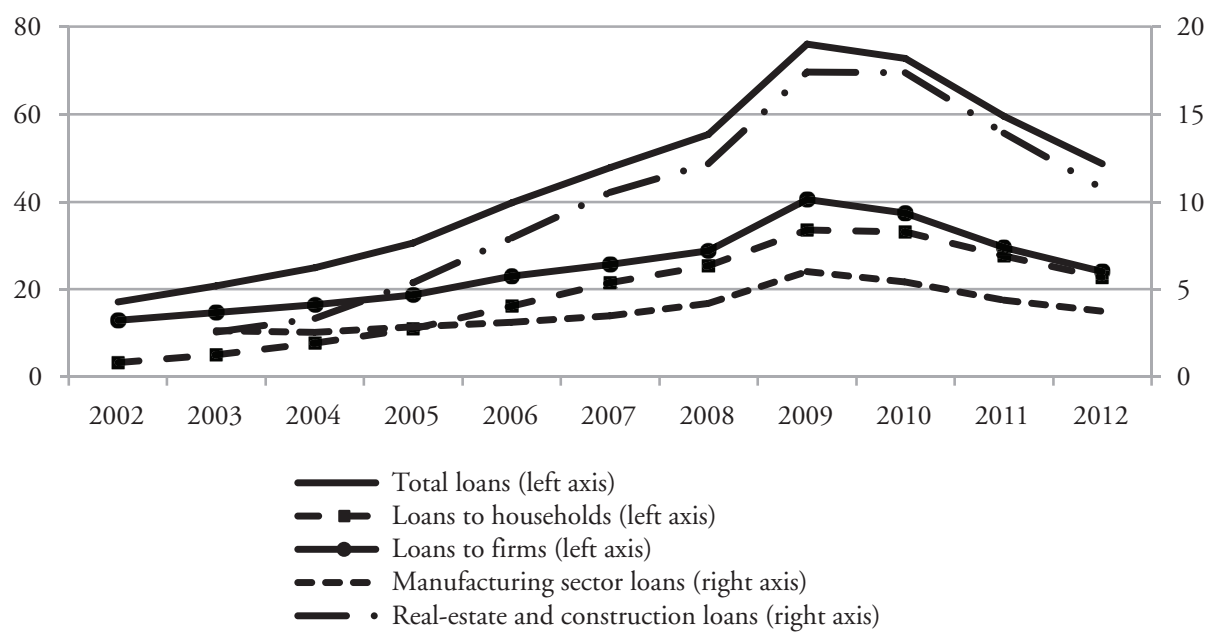

Source: Bank of Latvia (2014), author's calculation.

Figure 7 Composition of loans in Latvia (relative to GDP, per cent), 2002-2012

Despite the growth in the stock market after 2000, the main source of funding came from the banks. ${ }^{31}$

Owing to space constraints, I will now turn the focus of discussion towards the functionality of the financial system in Latvia. The first objective of the financial system is to provide sufficient finance for the private sector. It is important to mention that during the years of economic expansion, particularly after Latvia joined the EU, the amount of credit relative to GDP increased significantly (Figure 7). However, from 2010 onwards we can observe a strong decline. Although corporate sector loans increased during the economic boom, the rate of increase was rather modest, especially compared to household sector loans. ${ }^{32}$ Amidst and in the aftermath of the financial crisis, the rate of growth of loans to both sectors declined.

The analysis will proceed in such a way as to include the instruments available to the financial system to provide sufficient finance. For this purpose I am going to use the 'financial constraint' indicator of the World Bank. Using this indicator, we can say that during the periods of economic growth, firms seem to have been less financially constrained. ${ }^{33}$ However, during the financial crisis, the financial constraint increased dramatically. ${ }^{34}$ The last argument can be supported by analysing the indicator 'availability of finance', measured as the ratio of accepted bank loan requests-total loan requests (Eurostat 2014). Table 5 shows that there has been increased credit rationing in 2010 compared to 2007. Also, relative to the EU, Latvian companies faced more constraints in obtaining finance from the banks, which

31. In the period 2005-2008, 92 per cent of total assets belonged to the banks and the remaining 8 per cent to the nonbanks (EBRD 2009: 13).

32. Corporate loans include loans to financial and non-financial companies.

33. In fact, in 2005, only 2.5 per cent of all firms that participated in the survey responded that finance has been the major constraint to their operations (World Bank's Enterprise Surveys data). 34. In 2009, almost 28 per cent of all firms that participated in the survey responded that finance has been the biggest obstacle (World Bank's Enterprise Surveys data). 
Table 5 Availability of credit in the banking sector in Latvia

\begin{tabular}{lrrrr}
\hline & \multicolumn{2}{c}{ Latvia } & \multicolumn{2}{c}{ EU-13 } \\
\hline Sectoral composition & 2007 & 2010 & 2007 & 2010 \\
Total businesses (per cent) & 95.7 & 73.7 & 96.3 & 88.1 \\
Industry,d (per cent) & 90.9 & 63.0 & 96.7 & 89.5 \\
Wholesale and retail trade, real estate, & 100.0 & 79.6 & 96.1 & 87.9 \\
$\quad \begin{array}{llll}\text { transport, accommodation, food service, } \\
\text { and administrative activities (per cent) }\end{array}$ & & & & \\
\hline
\end{tabular}

Note: a. The availability of credit is calculated as a share of the accepted bank loan requests in total bank loan requests. The analysis covers only enterprises with 10 to 249 employees that were still active in 2008.

b. EU-13 is the non-adjusted mean average of the EU-15 countries, excluding Portugal and Austria due to a lack of data.

c. The availability of credit per sector shows the share of accepted bank loan requests relative to the bank loan requests in the respective sector.

d. Industry includes manufacturing, mining and quarrying, electricity and water supply sectors.

Source: Eurostat (2014), author's calculation.

can be seen by the smaller 'success' rate in obtaining loan finance, especially in the period of recession (Table 5).

To support industrial policy in increasing the importance of the manufacturing sector, the financial system's institutions are recommended to apply a strategy of channelling finance towards the 'productive' sectors (manufacturing sector) in the economy. The indicators I am going to use are the development of loans to the manufacturing sector-GDP ratio in the medium run and the availability of credit in the manufacturing sector. From Figure 7 it becomes clear that during the expansion phase the manufacturing sector loansGDP ratio has either stagnated or only slightly increased (which, is inter alia, not the case with the growth of loans to the real-estate and construction sectors). Looking at the 'availability of credit' per sector, we can conclude that there has been a striking increase in credit-rationing to the manufacturing sector in 2010 compared to 2007. Furthermore, the success of manufacturing firms in obtaining banks' finance has been much less satisfactory than the real-estate and construction sectors (Table 5).

In order to complete the assessment of the functionality of the financial system, I also need to address the second objective of the financial system, namely securing financial system stability. The first indicator I am going to look at is a banking crisis dummy. According to the Global Financial Development indicators of the World Bank, out of 16 years (from 1995 to 2011), Latvia had a banking crisis in 6, namely in 1995 and 1996 and for the whole period from 2008 through 2011. The second indicator is the non-performing loans-total loans ratio (Table 6). Compared to the period 1995-2007, when it amounted to 1.1 per cent on average, the non-performing loans-total loans ratio increased to 10.3 per cent during the financial and economic crisis, which confirms the fact that the financial system's fragility and instability increased during this period. As a result of the high capital inflows, foreign-currency loans-total loans ratio and foreign-currency deposits-total deposits ratio dramatically increased, which points towards a very high dollarisation/euroisation (Table 6). This development speaks of a loss of confidence in the domestic currency and capital flight, which increased during the period of financial crisis. Furthermore, the share of foreign-currency loans in the balance sheet of the households 
Table 6 Selected indicators for the level of dollarisation, currency mismatch and the size of non-performing loans in Latvia, 2002-2013

\begin{tabular}{lcc}
\hline & 2002-2007 & 2008-2013 \\
\hline $\begin{array}{l}\text { Share of foreign currency loans in total loans (per cent) } \\
\text { Share of foreign currency loans in loans to the financial } \\
\text { and non-financial corporations (per cent) }\end{array}$ & 63.5 & 60.1 \\
$\begin{array}{l}\text { Share of foreign currency loans in loans to households } \\
\text { (per cent) }\end{array}$ & 63.6 & 89.0 \\
$\begin{array}{l}\text { Share of foreign currency deposits in total deposits } \\
\text { (per cent) }\end{array}$ & 41.2 & 52.2 \\
\begin{tabular}{l} 
Non-performing loans (share of total loans, per cent) \\
\hline
\end{tabular}
\end{tabular}

Notes: a. Total loans are total resident loans (in domestic and foreign currency). The data do not include non-resident loans, loans to the government and loans to the monetary financial institutions. Source: Bank of Latvia's Macroeconomic Development Reports of various years, author's calculation. The source for the data on non-performing loans is World Bank (2014).

has increased in the period of a recession, which speaks of an increased currency mismatch and financial instability.

Moreover, even the regulatory measures which were undertaken during the financial crisis have not proven to have very positive results (ECB 2014: 118). The reasons were that they were introduced much too late and they did not contain foreign-currencyspecific provisions. ${ }^{35}$ Some of the major regulatory changes to strengthen the financial system's stability, which occurred in 2007 and 2009, were the introduction of a loan-tovalue ceiling of 90 per cent and additional capital requirements, but they did not contain a specific foreign-currency provision. Reserve requirements on foreign liabilities were introduced in 2005 and 2006, but they did not seem to be able to prevent the endogenous credit creation by the parent banks. A possible reason for this could be that the parent banks surpassed these regulations by increasing the equity of their subsidiaries in Latvia.

One strategy for the financial system institutions to follow is to discourage the creation of loans in the speculative sectors (real-estate and construction sectors) when there is a danger of an asset-price bubble. In Latvia particularly in the years preceding the financial and economic crisis, the real-estate loans and construction sector loans increased relative to the total non-financial corporate loans (Figure 7). This argument could let us conclude that the suggested strategy has also not been applied successfully.

To sum up, we can say that the financial system during the boom period seems to have provided the finance demanded. Yet during the recession the financial system failed to provide sufficient finance to the corporate sector. The standards of creditworthiness seem to have been strongly tightened, particularly at the expense of the companies operating in the manufacturing sector.

Moreover, the financial system institutions (the central bank, the government and financial supervisory agencies) failed to secure the stability of the former. High dollarisation and currency mismatch in the economic actors' balance sheets were allowed to develop due to the insufficient application as well as the inadequate and rather late

35. In 2010 a capital gains tax of 15 per cent, capital income tax of 10 per cent and financial stability duty of 0.036 per cent were introduced (MoF 2012). 
regulatory responses of financial system instruments. Thus we can argue that the development of the financial system was dysfunctional.

\subsection{Wage development/policy}

I will now briefly discuss the institutional framework surrounding wage development. After the breakdown of the Soviet Union, trade unions also had to go through a period of transformation, from unions 'close to the state' to independent social partners. Hence, trade union density declined from 28 per cent in 1995 to 16 per cent in 2007 (Visser 2011). Furthermore, there are no strong sectoral or national trade union federations or employers' associations. On a sectoral level, the agreements are mainly so-called 'framework agreements' setting the basic conditions, but the wage-related issues are dealt with in the individual companies. The dominant level of wage bargaining is the company level (Eurofound 2011). However, there are whole sectors where employers' associations do not exist and wages are more often than not set individually by the companies. ${ }^{36}$ Minimum wages and extension mechanisms of collective agreements have been used to increase wage coordination and support a higher involvement of the social partners, but with limited success.

As previously elaborated, wage policy should be given the task of maintaining the stability of the inflation rate in the medium run. The indicator that is going to show us whether this objective has been met is the medium-term development of the core inflation rate. Figure 8 shows the development of the latter. My first tentative observation could be that the inflation rate shows a relatively high volatility. This argument can be confirmed by the use of the standard deviation. The standard deviation of the core inflation rate for the period 1995-2013 amounts to 5.7 in Latvia, while in the EU average it equals $0.6 .^{37}$

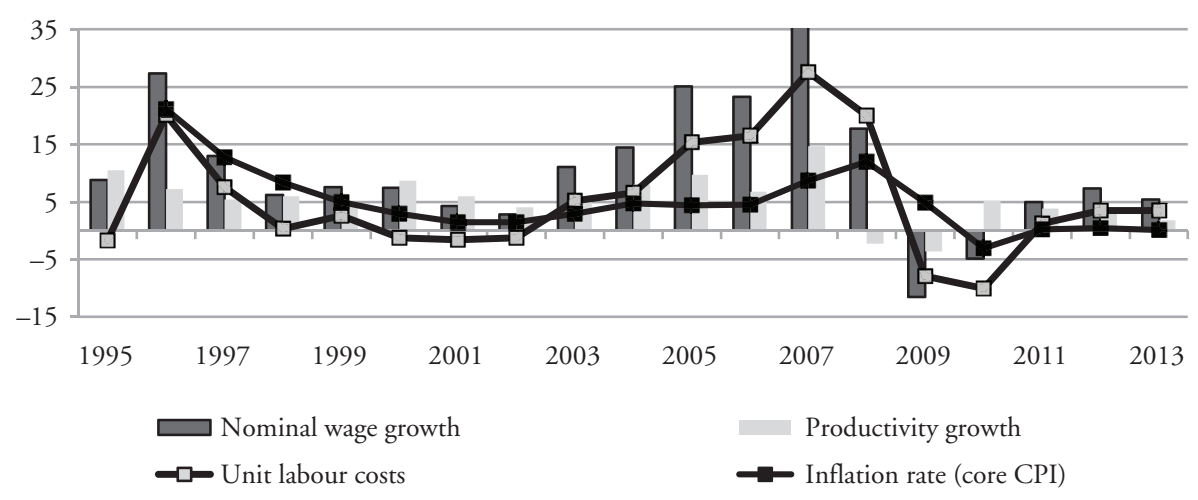

Notes: a. The figure shows the core CPI inflation rate (in per cent) and the growth of nominal wages, unit labour costs and productivity (as a year-on-year percentage change).

Source: Eurostat (2014), OECD (2014), author's calculation.

Figure 8 Wage indicators in Latvia, 1995-2013

36. The employer organisation density (that is, the share of employees employed in firms which are members of an employer association) was 30 per cent in 2009 (Eurofound 2009a).

37. Author's calculations based on OECD (2014). 
The next step is to look at the indicators that measure the functionality of wage policy instruments to maintain the stability of the inflation rate. First, I am going to look at the nominal wage development. Nominal wages have marked a dramatic increase particularly after joining the EU (Figure 8). One important factor causing a strong increase in nominal wages is the emigration of Latvian workers to the EU countries after $2004 .^{38}$ In 2008, as a part of the austerity measures imposed by the EU Commission and the EU governments, the government was forced to implement wage cuts in the public sector (Onaran 2011). The wage cuts in public administration led to a decline of wages in the private sector as well. Hence, the average wage declined by almost 13 per cent in 2009 and 6 per cent in 2010, which put pressure on unit labour costs and caused prices to fall. This decline in unit labour costs has been interpreted as an improvement of the competitiveness of the domestic companies during and shortly after the recent financial crisis, which stimulated higher exports and positively contributed to GDP growth. ${ }^{39}$ Yet from Figure 1 it becomes clear that the positive contribution of the improvement in net exports are to be seen only in 2008 and 2009, which means that this improvement occurred before the wage cuts took place and was largely a result of a stronger decline of imports below exports.

The second indicator, which is going to supplement the analysis of the functionality of wage policy instruments, is the extension of collective agreements. In the case of Latvia this mechanism has not been entirely successful, which can be seen in the low level of collective bargaining coverage. ${ }^{40}$ The latter remained at a low level, despite the fact that the possibility for extension of collective agreements has existed since 1995/1996 (Visser 2011). An important reason for the lack of success of this instrument is the limited number of sectors in which collective bargaining exists (which is a reflection of the very limited power of both trade unions and employers' associations). Another possible reason is the process of extension itself. ${ }^{41}$

Minimum wages can also be used to support wage coordination. The minimum wage has been used as an anchor for setting the 'basic' part of the nominal wage as a substitute for the weak collective bargaining (Eurofound 2009b). ${ }^{42}$ However, it is common practice to exclude the 'variable' part of the wage from the sectoral collective agreements, which leaves a lot of room for individual companies to decide on its size (Eurofound 2009b). This is one of the reasons why there appears to be a lack of wage coordination among (but also within) sectors and a reason for the increased volatility of nominal wage development. Moreover, in the absence of functional wage bargaining, the 'flexibility' of the 'variable' part of the wages has a pro-cyclical nature and poses a danger of deflationary development in a recession and inflationary development in a period of expansion.

38. Interview with Česlavs Gržibovskis from the Economic Policy Coordination Division of the Ministry of Economics of Latvia (10 May 2013, Ministry of Economics, Riga, Latvia).

39. In the interview I conducted with him, Česlavs Gržibovskis stressed that the success of achieving higher competitiveness of domestic firms was possible because of the 'weak' trade unions, which enabled the government to implement wage cuts (10 May 2013, Ministry of Economics, Riga, Latvia).

40. In 2008, collective bargaining coverage in Latvia was 25 per cent, while in the EU on average it was around 60 per cent (unweighted mean average, author's calculation based on Visser 2011).

41. Extension of collective agreements is possible under the condition that the signatories of the collective agreement employ at least 50 per cent of the workers or produce 60 per cent of the output in the whole sector and is published in Latvijas Vestnesis (CesIfo 2012).

42. Wages comprise a basic and a variable component. Each company decides on the size of the variable component, as well as the type of variable pay (financial pay and bonuses in kind). The companies in sectors with low collective bargaining coverage (especially SMEs) set the basic salary at the level of the minimum wage and the variable pay according to the individual employees' performance or the wages prevailing in the sector (Eurofound 2009b).). 
Table 7 Wage norm indicators in Latvia, average values, 1995-2013

\begin{tabular}{cccccc}
\hline & $\begin{array}{c}\text { Inflation } \\
\text { target } \\
\text { (per cent) }\end{array}$ & $\begin{array}{c}\text { Medium term } \\
\text { productivity } \\
\text { growth } \\
\text { (per cent) }\end{array}$ & $\begin{array}{c}\text { Nominal } \\
\text { wage } \\
\text { growth } \\
\text { (per cent) }\end{array}$ & $\begin{array}{c}\text { Wage } \\
\text { norm } \\
\text { (per cent) }\end{array}$ & $\begin{array}{c}\text { Deviation of wages } \\
\text { from the wage norm } \\
\text { (percentage points) }\end{array}$ \\
\hline $1995-2007$ & 5.7 & 5.6 & 14.9 & 11.3 & 3.6 \\
$2008-2013$ & 2.0 & 5.6 & 3.2 & 7.6 & -4.4 \\
\hline
\end{tabular}

Notes: a. Wage norm is calculated as the sum of the medium-term productivity increase and the inflation target.

b. Deviation of the wages from the wage norm shows the difference between the actual wage development and the wage norm.

Source: Eurostat (2014), author's calculation.

The wage norm for stability-oriented wage policy (that wage increases move in line with productivity development in the medium run plus the inflation target) is a criterion for assessing the functionality of the wage policy strategy. Given that the Latvian central bank does not have an explicit inflation target, the ECB's target of a 2 per cent inflation rate is assumed to be the inflation target the Bank of Latvia aims at. ${ }^{43}$ The indicator to assess whether this strategy has been followed is the deviation of the nominal wage increases from the wage norm in the medium run. From Table 7, we can conclude that the wage increases have been above the proposed wage norm for the period 1995-2007, which put additional pressure on inflation. In the period of economic crisis, the former has developed below the wage norm, which contributed to a deflationary development.

From the above, we can argue that the wage policy has not been successful in stabilising the inflation rate and through that also in stabilising the real exchange rate. Owing to the characteristics of the wage-setting institutional framework in Latvia (decentralised wage bargaining, low trade union density, weak trade unions and employers' associations), a functional wage policy has not been possible to conduct. There has been a dysfunctional use of wage policy instruments (nominal wages, extension mechanisms for collective agreements and minimum wages). The wage development did not seem to follow the suggested strategy of the so-called wage norm.

\subsection{Monetary policy}

In order to have a clear picture of the development of monetary policy in Latvia, we need to analyse the institutional setting and the most important institutional changes that have set the direction for monetary policy since the early 1990s. One crucial institutional change with respect to monetary policy was the creation of a two-tier system in 1988, when conditions for the establishment of the first private commercial banks were set (Barisitz 2002: 85). ${ }^{44}$ The Bank of Latvia was founded in 1990, setting maintenance of price stability as the primary monetary policy objective. It is not clear, though, what the

43. For the period 1995-1999, the actual inflation rate is taken as an implicit target for the Bank of Latvia; after 2000, when Latvia reached 2 per cent, the ECB's 2 per cent inflation-rate target is assumed to be the inflation target.

44. In 2014 Latvia entered the European Monetary Union, which is the second institutional change to have had a profound impact on the use of monetary (and fiscal) policy. However, due to space limitations, the period after 2014 will be omitted from this paper. 
central bank means by price stability or which inflation rate is targeted, as the central bank has neither announced nor published inflation targets. The Bank of Latvia attempted to maintain price stability through pegging the currency. In 1994 the currency was pegged to special drawing rights (SDR), including the US dollar, the German mark (later the euro), the pound sterling and the Japanese yen. In January 2005 the Lat was pegged to the euro, and a few months later the Lat entered the Exchange Rate Mechanism II, in order to fulfil the Maastricht criteria for accession to the EMU. In spite of the allowed fluctuation bands of 15 per cent around the arranged exchange-rate parity, the Latvian government unilaterally decided to keep the exchange rate within \pm 1 per cent fluctuation margins.

As elaborated earlier, a central bank should be given a task that is of high importance for the smooth functioning of the financial system and the whole economy, which is to secure the stability of the financial system. The role of the central bank in fulfilling this task has been analysed in Section 3.4. It was shown that there has been increased financial system instability during the periods directly preceding and succeeding the recent financial crisis.

Regarding the functionality of monetary policy instruments to achieve this goal, I am going to focus on credit allocation (as the other instruments have been discussed in Section 3.4). In the period under observation, the central bank has not been involved in the credit allocation of banks (for instance, in the form of direct credit or interest-rate ceilings). By July 1992 the lending and deposit interest rates of banks were already liberalised (EBRD 2003: 164).

Monetary policy is also given the task of providing sufficient low-cost finance to the banking system. Thus, I am going to look at the development of the real short-term interest rate minus GDP growth and the real long-term interest rate minus GDP growth. Both of the indicators were negative during the boom period, which fuelled up credit-driven consumption and investment (Table 8). In the years 2009 and 2010, real interest rates grew above the GDP growth, which caused a contraction of real investment. In the same years, as a result of disinflation and deflation, real interest rates turned positive, which demonstrates the limited ability of the central bank to use interest-rate policy to reduce the aggregate demand shocks in times of deflation. Moreover, we can argue that monetary policy during the crisis turned restrictive.

Table 8 Monetary policy indicators in Latvia, 1997-2013

\begin{tabular}{ccccccc}
\hline $\begin{array}{c}\text { Nominal } \\
\text { refinancing } \\
\text { interest } \\
\text { rate } \\
\text { (per cent) }\end{array}$ & $\begin{array}{c}\text { Interest rate } \\
\text { differentiala, }^{\text {(percentage }} \\
\text { points) }\end{array}$ & $\begin{array}{c}\text { RRIR }^{\mathrm{c}} \\
\text { (per cent) }\end{array}$ & $\begin{array}{c}\text { RRIR } \\
\text { minus GDP } \\
\text { growth } \\
\text { (percentage } \\
\text { points) }\end{array}$ & $\begin{array}{c}\text { RLIR } \\
\text { minus GDP } \\
\text { growth,e } \\
\text { (percentage } \\
\text { points) }\end{array}$ & $\begin{array}{c}\text { Foreign- } \\
\text { exchange } \\
\text { reserves/ } \\
\text { external } \\
\text { debt } \\
\text { (share, } \\
\text { per cent) }\end{array}$ \\
\hline $1997-2007$ & 4.0 & 0.9 & -0.9 & -8.7 & -9.0 & 19.4 \\
$2008-2013$ & 3.5 & 2.4 & -0.5 & 0.7 & 4.4 & 15.4 \\
\hline
\end{tabular}

Notes: a. Interest rate differential is calculated as the difference between the refinancing interest rate of the Bank of Latvia and that of the ECB.

b. Due to data unavailability for the ECB's refinancing rate of interest for the prior period, 1999 is used as the starting year for the calculation of the average values.

c. RRIR stands for real refinancing interest rate.

d. RLIR stands for real long-term interest rate.

e. Due to data unavailability, 2001 is used as the starting year for the calculation of the average values of the indicator RLIR minus GDP growth respectively.

Source: Eurostat (2014), author's calculation. 
The main instrument that a central bank can use to achieve its second objective is the shortterm interest rate. The central bank increased the interest rate between 2004 and 2007 to put a halt to the inflationary development, but because of the increased spread between this rate and the refinancing rate of the ECB, more capital was attracted to flow in (Eurostat 2014). ${ }^{45}$ The Bank of Latvia lowered the interest rate only in 2009, which can be interpreted as a rather late reaction. This cut in interest rates supplemented by the recessionary development of the economy stimulated a rise of capital outflows (Figure 4).

As explained earlier in the paper, a country can decide on the most optimal strategy to follow in terms of fulfilling the second objective of monetary policy. In the case of Latvia, because of the open capital account and the fixed exchange-rate regime, the central bank was in a sense unable to target low interest rates.

The functionality of monetary policy in meeting the third objective - preserving the stability of the exchange rate - will first be examined by looking at the exchange-rate development between the Lat (the Latvian currency) and the special drawing rights (SDR), and the exchange-rate development between the Lat and the euro. ${ }^{46}$ Figure 9 shows that both exchange rates have had a relatively low degree of fluctuation. According to my model of a macroeconomic policy regime, the central bank should maintain the stability of the exchange rate by intervening in the foreign-exchange markets. If we look at the Figure 9, we can observe that the central bank has intervened in the foreign-exchange market and was able to prevent the change of the exchange rates. These interventions are particularly remarkable after 2001. In 2008 and 2009, as a result of the capital withdrawal by the foreign banks from their subsidiaries, the domestic currency was put under pressure of depreciation, which in the framework of an open capital account and already exploding dollarisation, was expected to lead to a dangerous collapse of the

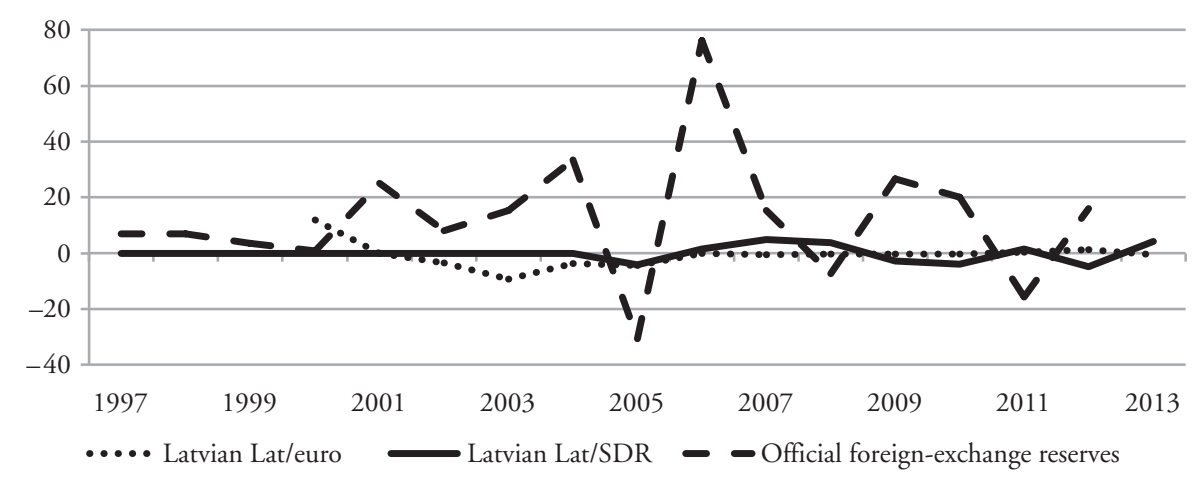

Note: a. Increase in the exchange rate means appreciation.

Source: World Bank (2014), Eurostat (2014).

Figure 9 Development of the exchange rate Latleuro, Lat/SDR and the growth of official foreign-exchange reserves in Latvia (1997-2013, per cent) ${ }^{\mathrm{a}}$

45. The nominal rate of interest increased from 4 per cent in 2004 to 6 per cent in 2007 (Eurostat 2014). Hence the spread to the ECB's nominal refinancing interest rate increased to 2.5 percentage points (author's calculation based on Eurostat 2014).

46. The reason for choosing these exchange rates is that the Latvian currency was pegged to the SDR until 2005 and to the euro thereafter. 
financial system (Onaran 2011: 224). In order to prevent the depreciation of the Lat and a complete collapse of the financial system, and taking into account the depletion of the foreign-exchange reserves available, the government was forced to ask the IMF and the ECB for a bail-out. ${ }^{47}$

As to the size of the foreign-exchange reserves, which are best suited to keep the exchange rate stable and, thus, prevent a collapse of the financial system, one argument is that the former should be maintained at a relatively high level (Priewe/Herr 2005). If we look at the development of the foreign-exchange reserves-external debt ratio, we can see that there has been a tendency towards a decline, which it can be argued poses a threat to the sustainability of the exchange-rate peg. This can be confirmed by the inability of the central bank to defend the exchange rate amidst the financial crisis (Table 8).

To conclude this section, we can say that the central bank failed in its attempt to protect the financial system from entering a crisis and that the instruments it used were either inadequate or insufficient for achieving this objective. Moreover, the central bank did not use credit allocation instruments to filter out the financing of speculative activities from the financing of productive activities in the economy.

The accomplishment of the second objective of monetary policy was jeopardised during the crisis. Before the crisis, the interest-rate policy seemed to be expansionary, but in recessionary times, it turned too restrictive. We can argue that the functional use of interest rates was constrained by the commitment of the central bank to defend the exchange rate and the open capital account.

The third objective of monetary policy has been met initially by a strong foreignexchange intervention. But, if it had not been for the bail-out package during the financial crisis, the shortage of foreign-exchange reserves would have made it impossible for the central bank to prevent a nominal depreciation of the domestic currency. Thus, with respect to fulfilling this objective, monetary policy was functional, albeit only partially.

\subsection{Fiscal policy}

The first institutional change affecting fiscal policy in Latvia is Latvia's accession into the EU and the government's commitment to fulfil the Maastricht fiscal criteria. These criteria had been met up until the outbreak of the financial crisis. However, the financial crisis of 2007/2008 caused a sharp decline in output, which resulted in an increase in budget deficits to 4 per cent in 2008 and 9 per cent in 2009 (Eurostat 2014).

The second institutional change is the adoption of the Euro Plus Pact in 2011, by which Latvia committed to incorporating the objectives of the EU related to 'sound finances' in its national law or constitution. As a consequence, the government endorsed the Fiscal Discipline Law, which came into effect in March 2013, which stipulates that:

[The] fiscal targets ${ }^{48}$ clearly show that Latvia is strongly committed to ensure the budget deficit in structural terms of not more than 0.5 per cent of GDP in coming years - starting already with 2015 the budget deficit in structural terms will be lower than the medium-term budget target for Latvia set by the EC. The realization of this kind of fiscal policy is an essential prerequisite for

47. The response of the EU in 2009 to provide financial assistance to Latvia was rather belated because the country had already fallen into recession in 2008 .

48. The targets are that the structural budget deficit does not exceed 1.4 per cent of GDP in 2013, 0.8 per cent of GDP in 2014 and 0.3 per cent of GDP in 2015 (ibid.: 4). 
Latvia to implement its strategic goal - to adopt the euro as of January 1, 2014. (The Government of Latvia 2012: 4)

In my interview with the Ministry of Economics, it was further pointed out that according to the Fiscal Discipline Law, 'the rate of growth of public expenditures should not exceed the average, ten-year-growth of potential GDP'. ${ }^{49}$ The institutional framework presented above seems to have posed certain limitations on the conduct of fiscal policy in Latvia, but this will be elaborated later.

The assessment of the functionality of fiscal policy will begin by analysing the success of fiscal policy in achieving the first objective, which is reducing the aggregate demand shocks in the economy. Figure 10 shows that there was a severe drop in output gap amidst the financial crisis, which implies that the actual growth of the economy has fallen below its potential output. ${ }^{50}$ One of the most effective instruments that a government can use to correct these aggregate demand shocks is discretionary government spending. I am going to use the indicator cyclically-adjusted budget balance-potential GDP ratio to assess the functional use of the instruments of fiscal policy. The first tentative observation that we can draw from Figure 10 is that while fiscal policy in the 1990s was mainly counter-cyclical, in the last 4 years before the crisis and between 2008 and 2009 it turned pro-cyclical. Second, the rate of growth of the aggregate government expenditure in the recession declined compared to the period of boom (Table 9). Moreover, the rate of growth of discretionary government spending was around zero per cent on average during the latest financial crisis, and public consumption grew at a rate of slightly above 1 per cent (Table 9). One major reason for this restrictive fiscal policy stance is that in the
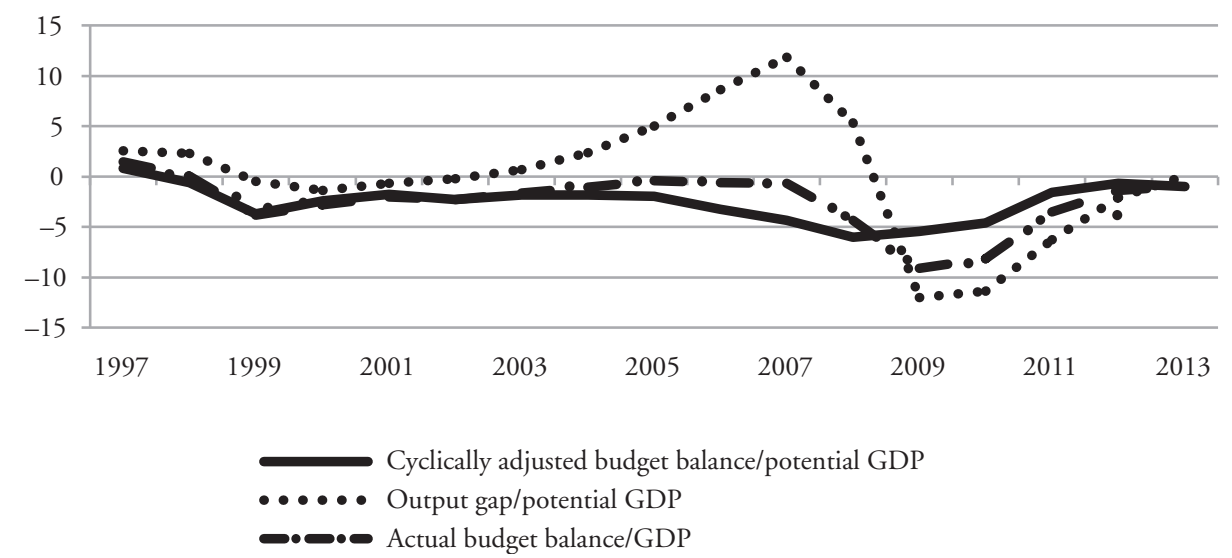

Source: Eurostat (2014).

Figure 10 Structural budget balance, actual budget balance and output gap in Latvia (per cent), 1997-2013

49. Interview with Česlavs Gržibovskis from the Economic Policy Coordination Division of the Ministry of Economics of Latvia (10 May 2013, Ministry of Economics, Riga, Latvia).

50. The size of the output gap relative to potential GDP during the expansion (1995-2007) was on average 2.8 per cent, while in the recession it reached an average of -4.4 per cent (author's calculation based on Eurostat 2014). 
Table 9 Structure of government spending per category in Latvia (average growth rate, per cent), 1996-2013

\begin{tabular}{lcc}
\hline & $1996-2007$ & 2008-2012 \\
\hline Government investment & 32.5 & -2.8 \\
Government consumption & 13.5 & 1.3 \\
Subsidies & 15.5 & 2.8 \\
Total discretionary government spending $^{\mathrm{a}}$ & 15.4 & 0.1 \\
Total government expenditure & 10.1 & 6.3
\end{tabular}

Notes: a. Total discretionary government spending is calculated as the sum of government investment, consumption and subsidies (see Hein/Truger 2007b for the methodology for calculating the cyclical and discretionary government expenditures).

Source: Author's calculation based on Eurostat (2014).

Memorandum of Understanding Between the European Community and the Republic of Latvia (2009), which was a part of the bail-out package, one of the conditions for the financial assistance to Latvia set by the European Community was fiscal consolidation. Thus, the government implemented six austerity packages between 2009 and 2012. ${ }^{51}$ Between 2008 and 2009, the structural budget deficit was reduced and a series of cuts in public spending followed, including a reduction in public sector wages.

As previously mentioned, the strategy recommendable for a more functional use of fiscal policy is to maintain a high level of public investment-GDP ratio. Particularly during the period of crisis, the government reduced the investment in capital formation and the rate of growth of the latter was negative (Table 9). In this respect, we can argue that the highly constraining institutional framework encompassed by the Euro Plus Pact and the Fiscal Discipline Law seems to have neglected the 'golden rule' that allows for structural deficits equivalent to net public investment over the cycle, and thus the importance of public investment (Hein/Truger 2014b).

The second objective of fiscal policy is to reduce income inequality. The Gini index of market income is the indicator of ex-post income inequality I am going to analyse. During the period 2006-2010, ${ }^{52}$ Latvia had more unequal income distribution compared to the countries in the EU (Table 10). The Gini index of disposable income will be used as an indicator for the effect of income redistribution policies by the government. Compared to the EU average, Latvia has also had a lower success in reducing income inequality. Moreover, Latvia is the country with the highest after-tax Gini coefficient of the whole EU (Eurostat 2014). Another important fact is that there is a flat tax rate of 25 per cent on personal income, which on the one hand does not speak of redistribution policies in favour of a more equal income distribution and on the other hand indicates a possible weakening of the automatic stabilisers.

Regarding the use of inheritance, property and wealth taxes in times of economic expansion as a strategy to reduce income inequality, we can say that until the present

51. To name a few examples, as a part of the budget consolidation programme, VAT was raised from 18 per cent to 22 per cent in 2012 (MoF 2012). The reduced VAT was increased from 5 per cent to 12 per cent. In the same year the personal income tax rate was raised from 23 per cent to 26 per cent.

52. Owing to the unavailability of comparable data for the remainder of the years, only the period 2006-2010 will be taken into consideration. 
Table 10 Gini coefficients for Latvia and the EU-15 (average for the period 2006-2010)

\begin{tabular}{lccc}
\hline & $\begin{array}{c}\text { Gini index of } \\
\text { market income }\end{array}$ & $\begin{array}{c}\text { Gini index of equivalised } \\
\text { disposable income }\end{array}$ & $\begin{array}{c}\text { Difference between 1st and } \\
\text { 2nd column }\end{array}$ \\
\hline Latvia & 41.3 & 37.0 & -4.3 \\
EU-15 $^{\text {b }}$ & 37.9 & 29.2 & -8.7 \\
\hline
\end{tabular}

Notes: a. Difference represents the success of the income redistribution policies of the government. It is the difference between the Gini index of market and disposable income.

b. EU-15 is the unweighted average of the EU-15 countries.

Source: European Commission (2014b).

day, wealth and inheritance taxes have been nonexistent in Latvia's taxation system. In April 2007 the government increased and differentiated certain duties and taxes on property, but much too late, as the growth in housing prices had already slowed down (European Commission 2012). ${ }^{53}$ Therefore, we can argue that the proposed strategy of increasing the aforementioned taxes in expansions has not been followed.

All in all, we can reach the following conclusions regarding the functionality of fiscal policy. During the financial crisis, fiscal policy failed to meet the first objective. The government attempted to reduce the budget deficit and resorted to restrictive fiscal policy, even though the country was still in a recession. Furthermore, during this period it did not even allow for automatic stabilisers to take effect. As a result of the Euro Plus Pact and the Fiscal Discipline Law, fiscal policy can be expected to show pro-cyclical tendencies and automatic stabilisers can be weakened further. Taking into consideration the drawbacks of the use of potential GDP for policy guidelines and its endogeneity, fiscal policy is likely to become not only pro-cyclical, but also quite restrictive in times of crisis. ${ }^{54}$

I cannot make a definite statement about the long or medium-term development of the redistribution policies of the government because of a lack of long-run data. However, I can assert that relative to the EU as a group, Latvia has marked a higher income inequality. Furthermore, the government had much less of a success in redistributing income towards low-income, low-wealth households than the EU countries, and one reason for this is that progressive taxation of personal income was not applied.

\section{CONCLUSIONS}

In this paper, one model of a functional MPR for emerging countries was presented. The model served as a benchmark for analysing economic development and assessing its functionality in the CEECs, applied specifically to the case of Latvia. In this model, foreign economic policy and industrial policy are assigned tasks of improving the current account by an economic restructuring in favour of production and exports of high-end products. The financial system is to provide sufficient finance especially to the manufacturing sector

53. These changes include: stamp duty on real-estate transactions; stamp duty on mortgage collateral registration; and tax on the difference realised between the property purchase and sale price (where the property has been held by the seller for less than 60 months) (ECB 2014: 118).

54. Estimates of potential GDP adjust to changes in actual GDP growth; hence, if Latvia's economy slows down or enters a recession, a downward adjustment of potential GDP is also to be expected, which would under the Fiscal Compact and the Fiscal Discipline Law necessitate procyclical fiscal consolidation policies (for the exposition on Germany, see Hein/Truger 2014a). 
and provide stability in the financial sector. The case of Latvia also clearly shows that wage development is a very important factor in determining prices. Therefore, providing a stable wage anchor would help stabilise the inflation rate and keep the real exchange rate stable. Monetary policy is given the task of maintaining financial system stability, providing low-cost finance and defending the exchange rate. Fiscal policy is mainly in charge of combating shocks to aggregate demand and reducing income inequality.

The findings of the empirical part about the development of the MPR in Latvia can be summarised as follows:

1. Institutional changes as a result of the deregulation of financial, goods and labour markets that took place in Latvia set limits to the macroeconomic policy mix used. Taking the example of Latvia, foreign economic policy allowed for a quick and extensive capital account liberalisation, which led to a relatively high capital volatility (and capital outflows during the recent crisis), dollarisation/euroisation and currency mismatches in the balance sheets of the economic actors. Furthermore, the capital surges stimulated an accumulation of current-account deficits. Foreign economic policy was not successful in reducing the current-account deficits and balancing the current account in the medium to long run. Its policy instruments were not used in a functional way so they failed to increase the income elasticity of exports. Current-account deficits after the period of crisis reappeared again, which suggests that there is an urgent need for a strategy to increase the non-price competitiveness of Latvian companies.

2. One necessary condition is to engage industrial policy in restructuring the economy in favour of the manufacturing sector, particularly the high-innovation, high-technology sectors. In Latvia we could observe a strong de-industrialisation and a shift of economic activity towards the real-estate and financial sector. The government seems to have contributed little to stop this process and even less to support a revival of the manufacturing sector.

3. In the domestic financial system, endogenous credit was created by the foreign parent banks, which channelled large amounts of funds to finance the companies operating in the real-estate and construction sectors and to households in the form of a mortgage credit, supporting the rise in the asset-price bubble. Generally speaking, there was strong credit creation towards the business sector in the boom period. However, in the recession, the growth of corporate credit declined and the manufacturing companies compared to other sectors were more financially constrained (especially SMEs). Financial system institutions (including the central bank) did not manage to maintain the stability of the financial system. There has been a lack of adequate financial system instruments to prevent the creation of the asset-price bubble and to put a halt to the large increase in dollarisation and currency mismatch.

4. The strong rise in the asset-price bubble put pressure on the central bank to increase interest rates before the recent crisis. But these interest rate increases resulted, on the one hand, in increased capital imports and, on the other hand, they seem not to have been sufficiently high to stop the overheating of the economy. The interest rate was only cut in 2009, which was a belated measure. Particularly under the framework of an open capital account and fixed exchange rate regime, 'fine-tuning' of the economy via interest rates is not possible, which was confirmed in the case of Latvia. In the situation of increasing current-account deficits and an overvalued domestic currency, it becomes difficult to defend the exchange rate with foreign-exchange intervention.

5. Deregulated labour markets, decentralised wage bargaining (which was nonexistent in many sectors/companies) and low wage coordination can put additional pressure 
on the stability of the inflation rate and can cause deterioration in the competitiveness of domestic firms. Minimum wages and the extension of collective agreements have been used to substitute wage bargaining, but with very low success in terms of increasing wage coordination. This proves the argument that collective bargaining is necessary for wage policy to function properly.

6. Fiscal policy was highly pro-cyclical during the financial crisis. The government resorted to budget consolidation policies, including cuts in public investment, which drove the economy into an even deeper recession. Moreover, fiscal policy instruments were not used in a functional way so they failed to reduce high income inequality.

7. Therefore, we can speak of a relatively dysfunctional MPR in times of both boom and recession, which created conditions for unstable growth, current-account deficits, an unstable inflation rate and unequal income distribution.

This paper provided an alternative model of a functional MPR based on post-Keynesian economics. It showed that sacrificing external balance for higher economic growth is not a sustainable strategy in the long term. Thus, the recommendation is that a bigger focus is put on foreign economic policy and industrial policy, to help rebuild the competitiveness of the exporting sector and contribute to a reduction in current-account deficits, achieving a balanced current account. Hopefully, the analysis of the MPR in Latvia presented in this paper can stimulate research on the MPRs of other emerging countries.

\section{REFERENCES}

Andersone, E., Bogdanova, O. (2013): The role of export credit guarantees in the improvement of business environment in the European Union, in: Economics and Business, Scientific Paper Series, Riga Technical University.

Arestis, P., Sawyer, M. (2004): On fiscal policy and budget deficits, in: Intervention: Journal of Economics and Economic Policies, 1(2), 61-74.

Arestis, P., Sawyer, M. (2011): A new paradigm for macroeconomic policy, in: International Journal of Public Policy, 7(1/2/3), 22-39.

Bajo-Rubio, O., Díaz-Roldán, C. (2009): Does the balance of payments constrain the economic growth? Some evidence for the new EU members, in: Post-Communist Economies, 21(1), 41-46.

Bank of Latvia (2014), URL: http://www.bank.lv (accessed September 2014).

Barisitz, S. (2002): Banking in the Baltics - the development of the banking systems of Estonia, Latvia and Lithuania since independence. The emergence of market-oriented banking systems in Estonia, Latvia and Lithuania (1988-1997), in: Österreichische Nationalbank, 2, 84-106.

Central Statistical Office of Latvia (2014): Statistical database, URL: http://www.csb.gov.lv/en (accessed September 2014).

CesIfo (2012): Collective Bargaining Levels and Coverage, 2010: International Comparisons, DICE Database, Munich.

Chang, H.J. (1994): The Political Economy of Industrial Policy, New York: St Martin's Press.

Chang, H.J. (2006): Industrial policy in East Asia: lessons for Europe, in: An Industrial Policy for Europe? From Concepts to Action, European Investment Bank (EIB) Papers, 11(2), 106-133.

Chang, H.J. (2010): Industrial policy: can we go beyond an unproductive confrontation?, Turkish Economic Association Discussion Paper 2010/1, January, Ankara.

Chinn, M., Ito, H. (2006 [2013]): Database available at URL: http://web.pdx.edu/ -ito/Chinn-Ito_ website.htm. (First published in: Chinn, M., Ito, H. (2006): What matters to financial development? Capital controls, institutions and interactions, in: Journal of Development Economics, 81(1), 163-192.)

Dombrovsky, V. (2010): Does Latvia need an industrial policy?, Discussion Paper, President's Strategic Analysis Commission, January, Riga. 
EBRD (European Bank for Reconstruction and Development) (2003): Transition report 2003: integration and regional cooperation, URL: http://www.ebrd.com/downloads/research/transition/ TR03.pdf.

EBRD (European Bank for Reconstruction and Development) (2009): Transition report 2009: transition in crisis?, URL: http://www.ebrd.com/downloads/research/transition/TR09.pdf.

ECB (European Central Bank) (2014): Financial stability review, May 2014, Frankfurt am Main, URL: http://www.ecb.europa.eu/pub/pdf/other/financialstabilityreview201405en.pdf (accessed August 2014).

Eurofound (2009a): Latvia: industrial relations profile, URL: http://www.eurofound.europa.eu/eiro/ country/latvia.pdf (accessed April 2014).

Eurofound (2009b): Latvia: wage flexibility and collective bargaining, URL: http://www.eurofound. europa.eu/eiro/studies/tn0803019s/lv0803019q.htm (accessed April 2014).

Eurofound (2011): Recent developments in wage setting and collective bargaining in the wake of the global economic crisis, URL: http://www.eurofound.europa.eu (accessed March 2014).

European Commission (2012): Real-estate price dynamics, housing finance and related macro-prudential tools in the Baltics, in: ECFIN Country Focus, 9(2), URL: http://ec.europa.eu/economy_finance/ publications/country_focus/2012/2012/cf_vol9_issue2_2012.pdf.

European Commission (2014a): State-aid scoreboard, URL: http://ec.europa.eu/competition/ state_aid/scoreboard/ (accessed September 2014).

European Commission (2014b): Social situation monitor: income inequality, URL: http://ec. europa.eu/social/main.jsp?catId=1050\&intPageId=1869 (accessed September 2014).

Eurostat (2014): Online statistical database, URL: http://epp.eurostat.ec.europa.eu/portal/page/ portal/monetary_financial_statistics/data/database (accessed October 2014).

Government of Latvia, The (2012): Convergence programme of the Republic of Latvia 2012-2015, URL: http://www.ec.europa.eu/europe2020/pdf/nd/cp2012_latvia_en.pdf (accessed September 2014).

Hein, E. (2005): Finanzstruktur und wirtschaftswachstum: theoretische und empirische aspekte, Macroeconomics, IMK at the Hans Boeckler Foundation, Macroeconomic Policy Institute, IMK Studies, Paper No 01-2005.

Hein, E., Stockhammer, E. (2011): A Post-Keynesian macroeconomic model of inflation, distribution and employment, in: Hein, E., Stockhammer, E. (eds), A Modern Guide to Keynesian Macroeconomics and Economic Policies, Cheltenham, UK and Northampton, MA: Edward Elgar, 112-136.

Hein, E., Truger, A. (2005): European Monetary Union: nominal convergence, real divergence and slow growth?, in: Structural Change and Economic Dynamics, 16(1), 7-33.

Hein, E., Truger, A. (2007a): Germany's post-2000 stagnation in the European context: a lesson in macroeconomic mismanagement, in: Arestis, P., Hein, E., Le Heron, E. (eds), Aspects of Modern Monetary and Macroeconomic Policies, Basingstoke, UK: Palgrave Macmillan, 223-247.

Hein, E., Truger, A. (2007b): Fiscal policy and macroeconomic performance in the euro area: lessons for the future, in: Bibow, J., Terzi, A. (eds), Euroland and the World Economy: Global Player or Global Drag?, Basingstoke, UK: Palgrave Macmillan, 154-183.

Hein, E., Truger, A. (2014a): Fiscal policy and re-balancing in the Euro area: a critique of the German debt brake from a Post-Keynesian perspective, in: Panoeconomicus, 1, 21-38.

Hein, E., Truger, A. (2014b): Future fiscal and debt policies: Germany in the context of the European Monetary Union, in: Arestis, P., Sawyer, M. (eds), Fiscal and Debt Policies for the Future, Basingstoke, UK: Palgrave Macmillan, 76-115.

Heine, M., Herr, H., Kaiser, C. (2006): Wirtschaftspolitische Regime westlicher Industrienationen, Baden-Baden: Nomos.

Hein, E., Truger, A., van Treeck, T. (2012): The European financial and economic crisis: alternative solutions from a (Post-) Keynesian perspective, in: Arestis, P., Sawyer, M. (eds), The Greek and the Euro Area Crises, International Papers in Political Economy, Basingstoke, UK: Palgrave Macmillan, 35-78.

Herr, H. (2008): Financial systems in developing countries and economic development, in: Hein, E., Niechoj, T., Spahn, P., Truger, A. (eds), Finance-Led Capitalism: Macroeconomic Effects of Changes in the Financial Sector, Marburg: Metropolis, 123-150. 
Herr, H. (2014): An analytical framework for the Post-Keynesian macroeconomic paradigm, in: Izmir Review of Social Sciences, 1(2), 73-105.

Herr, H., Kazandziska, M. (2007): Wages and regional coherence in the European Monetary Union, in: Hein, E., Priewe, J., Truger, A. (eds), European Integration in Crisis, Marburg: Metropolis, 131-162.

Herr, H., Kazandziska, M. (2011a): Principles of minimum wage policy: economics, institutions and recommendations, Global Labour University Working Paper, No 11.

Herr, H., Kazandziska, M. (2011b): Macroeconomic Policy Regimes in Western Industrial Countries, Abingdon, UK: Routledge.

IMF (International Monetary Fund) (2008): Annual report on exchange arrangements and exchange restrictions, Washington, DC: International Monetary Fund, 769-776.

Kaldor, N. (1970): The case for regional policies, in: Targetti, F., Thirlwall, A.P. (eds), The Essential Kaldor, London: Duckworth, 311-326.

Keynes, J.M. (1937): The 'ex-ante' theory of interest, in: The Economic Journal, 47, 663-669.

Kvedaras, V. (2005): Explanation of economic growth differences in the CEE countries: importance of the BOP constraint, in: Baltic Journal of Economics, Summer/Autumn, 48-65.

Levine (2005): Finance and growth: theory and evidence, in: Aghion, P., Durlauf, S. (eds), Handbook of Economic Growth, 1, 865-934.

Lux, G. (2009): The re-emerging role of industry in Central European economies, in: Baranyi, W.B., Fodor, I. (eds), The Role of Environmental Industry in the Regional Reindustrialisation in Hungary, Debrecen-Pécss: Hungarian Academy of Sciences, Centre for Regional Studies, 19-35.

Memorandum of Understanding Between the European Community and the Republic of Latvia (2009), 26 January, URL: http://ec.europa.eu/economy_finance/articles/financial_operations/ article13872_en.htm (accessed May 2014).

Mencinger, J. (2007): Addiction to FDI and current account balance, in: Becker, J., Weissenbacher, R. (eds), Dollarization, Euroization and Financial Fragility: Central and Eastern European Countries between Stagnation and Financial Crisis?, Marburg: Metropolis, 109-126.

MoE (Ministry of Economics of the Republic of Latvia) (2013): Economic development of Latvia, Riga, June, URL: http://www.em.gov.lv/files/tautsaimniecibas_attistiba/e2013jun.pdf (accessed June 2014).

MoF (Ministry of Finance of the Republic of Latvia) (2012): Tax system in Latvia, URL: http://www.fm.gov.lv/en/s/taxes (accessed June 2014).

OECD (2014): Statistical database, URL: http://stats.oecd.org (accessed May 2014).

Onaran, Ö. (2011): From transition crisis to the global crisis: twenty years of capitalism and labour in the Central and Eastern EU new member states, in: Capital and Class, 35(2), 213-231.

Onaran, Ö., Galanis, G. (2012): Is aggregate demand wage-led or profit-led? National and global effects, in: Conditions of Work and Employment Series, 40, Geneva: International Labour Office.

Palley, T.I. (2000): Stabilizing finance: the case for asset-based reserve requirements, in: Financial Markets and Society Series, Philomont: Financial Markets Centre.

Palley, T.I. (2004): Asset-based reserve requirements: reasserting domestic monetary control in an era of financial innovation and instability, in: Review of Political Economy, 16(1), 43-58.

Palley, T.I. (2006): A Post-Keynesian framework for monetary policy: why interest rate operating procedures are not enough?, in: Gnos, C., Rochon, L.-P. (eds), Post-Keynesian Principles of Economic Policy, Cheltenham, UK and Northampton, MA: Edward Elgar, 78-100.

Priewe, J. (2008): Capital account management or laissez-faire of capital flows in developing countries, in: Arestis, P., de Paula, L.F. (eds), Financial Liberalization and Economic Performance in Emerging Countries, Basingstoke, UK: Palgrave Macmillan, 26-51.

Priewe, J. (2012): Capital account management in developing countries, in: Virtual Institute, Geneva: United Nations Conference on Trade and Development (UNCTAD), January, URL: http://sf.cufe.edu.cn/docs/2012-10/20121015084625890426.pdf (accessed June 2014).

Priewe, J., Herr, H. (2005): The Macroeconomics of Development and Poverty Reduction: Strategies Beyond the Washington Consensus, Baden-Baden: Nomos.

Rochon, L.-P., Rossi, S. (2007): Central banking and Post-Keynesian economics, in: Review of Political Economy, 19(4), 539-554. 
Sawyer, M. (2011): Rethinking macroeconomic policies, in: Gnos, C., Rochon, L.-P. (eds), Credit, Money and Macroeconomic Policy: A Post Keynesian Approach, Cheltenham, UK and Northampton, MA: Edward Elgar, 268-288.

Thirlwall, A.P. (1979): The balance of payments constraint as an explanation of international growth rate differences, in: Banca Nazionale del Lavoro Quarterly Review, 128, 45-53.

Thirlwall, A.P. (2011): Economics of Development Theory and Evidence, Basingstoke, UK: Palgrave Macmillan.

Thirlwall, A.P. (2013): Economic Growth in an Open Developing Economy: The Role of Structure and Demand, Cheltenham, UK and Northampton, MA: Edward Elgar.

Visser, J. (2011): Database on institutional characteristics of trade unions, wage setting, state intervention and social pacts, 1960-2010 (ICTWSS), URL: http://www.uva-aias.net/208 (accessed August 2014).

Warwick, K. (2013): Beyond industrial policy: emerging issues and new trends, in: OECD Science, Technology and Industry Policy Papers, 2, Paris: OECD Publishing.

World Bank (2014): World Development Indicators, URL: http://data.worldbank.org/data-catalog/ world-development-indicators (accessed September 2014). 